\title{
IMPLEMENTASI MIKROKONTROLER ATMEGA328 DI BIDANG PERTANIAN DAN INDUSTRI
}




\section{Sanksi Pelanggaran Pasal 113 Undang-Undang}

\section{Republik Indonesia Nomor 28 Tahun 2014 Tentang Hak Cipta}

1. Hak Cipta adalah hak eksklusif pencipta yang timbul secara otomatis berdasarkan prinsip deklaratif setelah suatu ciptaan diwujudkan dalam bentuk nyata tanpa mengurangi pembatasan sesuai dengan ketentuan peraturan perundang-undangan. (Pasal 1 ayat [1]).

2. Pencipta atau Pemegang Hak Cipta sebagaimana dimaksud dalam Pasal 8 memiliki hak ekonomi untuk melakukan: a. Penerbitan ciptaan; b. Penggandaan ciptaan dalam segala bentuknya; c. Penerjemahan ciptaan; d. Pengadaptasian, pengaransemenan, atau pentransformasian ciptaan; e. pendistribusian ciptaan atau salinannya; f. Pertunjukan Ciptaan; g. Pengumuman ciptaan; h. Komunikasi ciptaan; dan i. Penyewaan ciptaan. (Pasal 9 ayat [1]).

3. Setiap Orang yang dengan tanpa hak dan/atau tanpa izin Pencipta atau pemegang Hak Cipta melakukan pelanggaran hak ekonomi Pencipta sebagaimana dimaksud dalam Pasal 9 ayat (1) huruf $a$, huruf $b$, huruf e, dan/atau huruf g untuk Penggunaan Secara Komersial dipidana dengan pidana penjara paling lama 4 (empat) tahun dan/atau pidana denda paling banyak Rp1.000.000.000,00 (satu miliar rupiah). (Pasal 113 ayat [3]).

4. Setiap Orang yang memenuhi unsur sebagaimana dimaksud pada ayat (3) yang dilakukan dalam bentuk pembajakan, dipidana dengan pidana penjara paling lama 10 (sepuluh) tahun dan/atau pidana denda paling banyak Rp4.000.000.000,00 (empat miliar rupiah). (Pasal 113 ayat [4]). 
Folkes Laumal

\section{IMPLEMENTASI MIKROKONTROLER ATMEGA328 DI BIDANG PERTANIAN DAN INDUSTRI}


Katalog Dalam Terbitan (KDT)

(C) Folkes Laumal

Implementasi Mikrokontroler ATMEGA328 di Bidang Pertanian dan Industri/Folkes Laumal. -- Yogyakarta: Samudra Biru, 2017.

$\mathrm{xii}+70 \mathrm{hlm}$. ; $14 \times 20 \mathrm{~cm}$.

ISBN : 978-602-6295-85-9

Hak cipta dilindungi oleh Undang-undang. Dilarang mengutip atau memperbanyak sebagian atau seluruh isi buku ini dalam bentuk apapun juga tanpa izin tertulis dari penerbit.

Cetakan I, Oktober 2017

Tim Penyusun : Folkes Laumal

Editor : Alviana Cahyanti

Desain Sampul: Roslani Husein

Layout : Joko Riyanto

\section{Diterbitkan oleh:}

\section{Penerbit Samudra Biru (Anggota IKAPI)}

Jln. Jomblangan Gg. Ontoseno B.15 RT 12/30

Banguntapan Bantul DI Yogyakarta

Email/FB : psambiru@gmail.com

website: www.cetakbuku.biz/www.samudrabiru.co.id

Phone: 0813-2752-4748 
"Teruntuk Agustina Lado (ibu), Patrisia X. Djami (Istri) dan Chaterine C. Laumal (Anak) atas semua dukungan doa selama saya menyelesaikan penelitian dan menyiapkan $6 u k u$ " 



\section{Kata Pengantar}

Puji syukur kami panjatkan ke hadirat Tuhan Yang Maha Esa, yang atas penyertaan dan karunia-Nya kami dapat menyelesaikan buku ini. Buku ini diberi judul Implementasi Mikrokontroler Atmega328 di Bidang Pertanian dan Industri. Secara garis besar buku ini membahas tentang bagaimana mengimplementasikan komponen-komponen elektronika yang dikombinasikan dengan teknologi informatika menjadi sebuah sistem yang dapat dimanfaatkan dalam bidang pertanian dan industri.

Melihat perkembangan teknologi komunikasi, elektronika dan informatika saat ini yang begitu maju, telah mendorong pemikiran untuk memanfaatkan sumber daya tersebut untuk memenuhi kebutuhan manusia. Terdorongnya pemikiran untuk melakukan inovasi dan mengembangkan teknologi yang ada, telah banyak menstimulasi dikembangkannya pemanfaatan teknologi berdasarkan ilmu pengetahuan yang pada akhirnya memudahkan 
manusia menyelesaikan berbagai persoalan.

Sebagai karya yang besumber dari hasil dua riset terapan yang memanfaatkan teknologi mikrokontroler pada sistem pengatur irigasi dan mesin bubut, kami membagi pembahasannya ke dalam dua bagian terpisah agar memudahkan pembaca dalam mendalami masing-masing materi. Bagian pertama, yakni tentang sistem irigasi pintar berbasis mikrokontroler akan dibahas pada bab I, sedangkan bagian kedua yakni tentang pengembangan sensor getar berbasis mikrokontroler untuk memonitoring mesin bubut horizontal akan dibahas pada bab II.

Riset yang pertama secara umum membahas tentang bagaimana merancang sistem irigasi pintar berbasis mikrokontroler sebagai pengembangan dari sistem irigasi manual, bagaimana membangun protokol (software) layanan pada sistem irigasi pintar berbasis mikrokontroler agar aktivitas petani lebih maksimal dan bagaimana membangun layanan kontrol berbasis client-server untuk saluran irigasi primer-sekunder-tersier, sehingga terbangun sistem irigasi pintar terpadu.

Sedangkan pada riset kedua, secara umum membahas tentang bagaimana merancang sensor getar berbasis mikrokontroler, bagaimana mengkalibrasi sensor getar berbasis mikrokontroler agar dapat dimanfaatkan untuk monitoring getaran realtime mesin bubut horizontal serta bagaimana menentukan nilai ideal sensor getar terhadap getaran mesin bubut horizontal.

Penulis menyadari bahwa buku ini bukanlah tanpa kelemahan, untuk itu kritik dan saran sangat diharapkan. Kami dari tim penulis sangat berbesar harap semoga buku ini dapat bermanfaat bagi para pembacanya. Akhir kata, selamat membaca, tentunya. 


\section{Daftar Isi}

KATA PENGANTAR ................................................ vii

DAFTAR ISI ......................................................... ix

DAFTAR GAMBAR.............................................. xi

DAFTAR TABEL ................................................... xiii

BAB I SISTEM IRIGASI PINTAR BERBASIS MIKROKONTROLER PADA DAERAH IRIGASI UNTUK PENINGKATAN HASIL PERTANIAN
A. Deskripsi Permasalahan 1
B. Metode dan Diagram Riset .......................................... 3
C. Konsep-Konsep Teoritis ............................................ 5
D. Implementasi Teknologi Mikrokontroler Pada Sistem
E. Irigasi ................................................................. 15 


\section{BAB II PENGEMBANGAN SENSOR GETAR BERBASIS MIKROKONTROLER UNTUK MONITORING GETARAN MESIN BUBUT HORIZONTAL}
A. Deskripsi Permasalahan
B. Metode dan Diagram Riset
C. Konsep-Konsep Teoritis
D. Implementasi Teknologi Mikrokontroler Pada Mesin Bubut Horizontal 31 33

\section{BAB VI PENUTUP}

Kesimpulan dan Saran.

DAFTAR PUSTAKA................................................. 59

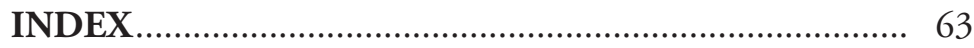

TENTANG PENULIS .............................................. 67 


\section{Daftar Gambar}

Gambar 1. Diagram Blok Sistem Pengendalian Loop

Terbuka ........................................................... 6

Gambar 2. Diagram Blok Sistem Kontrol Tertutup .............. 6

Gambar 3. Pintu Air Irigasi di DI Manikin .......................... 10

Gambar 4. Pin Mikrokontroler ATMega328 …..................... 10

Gambar 5. Tampilan Arsitektur ATMega328 ....................... 14

Gambar 6. Diagram Hardware Sistem Kontrol Pintu Air

Irigasi ............................................................ 15

Gambar 7. Interkoneksi Pintu Air Irigasi Pintar ................... 17

Gambar 8. Rancangan Algoritma Sistem Kontrol Pintu Air .. 19

Gambar 9. Topologi Jaringan Point-to-point ........................ 34

Gambar 10. Topologi Jaringan Multidrop ……………......... 35

Gambar 11. Protokol komunikasi model referensi OSI ......... 37

Gambar 12. Protokol komunikasi model TCP/IP.................. 38

Gambar 13. Embedded Web Server ATmega328 ....................... 41 
Gambar 14. Skema Rangkaian Embedded Web Server ATmega328 ..................................................... 41

Gambar 15. (a) XBee 1mW Wire Antenna, (b) Skema Rangkaian Xbee …………………………...... 42

Gambar 16. Accelerometer tipe MMA7361 ........................... 43

Gambar 17. Mesin Bubut CNC........................................ 44

Gambar 18. Bad Mesin bubut (Lathe bed) ............................. 44

Gambar 19. Tailstock ......................................................... 47

Gambar 20. Konfigurasi tombol operasipada TU-2A ........... 47

Gambar 21. Rancangan Sensor Getar.................................. 50

Gambar 22. Sensor Getar dengan ADXL335 ……............... 50

Gambar 23. Rancangan aliran data dari sensor ADXL335.... 51

Gambar 24. Proses Kalibrasi Sensor....................................... 53

Gambar 25. Output getaran sebelum dan sesudah

dikalibrasi................................................... 54 


\section{Daftar Tabel}

Tabel 1. Simulasi pengoperasian pintu air irigasi pintar berbasis Atmega328................................................ 26

Tabel 2. Pengujian waktu RTC terhadap perilaku port di Atmega328 Arduino............................................... 27

Tabel 3. Pengujian Arus pada masing-masing Relay berdasarkan waktu yang ditentukan.......................... 28

Tabel 4. Pembagian range IP ................................................. 39 



\section{1}

\section{Sistem Irigasi Pintar Berbasis Mikrokontroler Pada Daerah Irigasi untuk Peningkatan Hasil Pertanian}

\section{A. Deskripsi Permasalahan}

Kupang merupakan salah satu kabupaten di Nusa Tenggara Timur dengan luas 542.397 hektar. Secara geografis, Kupang merupakan kabupaten paling selatan di Indonesia dan menjadi pintu gerbang antara Timor Leste dengan ibukota propinsi NTT, yakni terletak diantara $09^{\circ} 19^{\prime}-10^{\circ} 57^{\prime}$ LS dan $121^{\circ} 31^{\prime}-124^{\circ} 1 l^{\prime}$ BT (Temu et al, 1999). Data dari Dinas Pertanian dan Perkebunan Kabupaten Kupang mengatakan bahwa 3,48 \% dari total luas wilayah Kabupaten Kupang, merupakan lahan sawah kering yang memanfaatkan air bendungan dan sumur bor sebagai irigasi usaha pertanian masyarakat.

Lokasi lahan sawah di Kabupaten Kupang yang paling dikenal menghasilkan beras adalah daerah Manikin, Tilong dan Oesao, dengan tingkat pendapatan padi di tiga wilayah pernah mencapai pertumbuhan antara 4t/ha - 6.5t/ha di awal tahun 2000- 
an (Juknis Pra Rima Tani, 2004). Salah satu faktor pendukung saat itu adalah ketersediaan saluran irigasi dan pengelolaan yang baik oleh kelompok petani. Saat ini ketiga daerah tersebut telah menjadi Daerah Irigasi (DI) dengan Manikin sebagai wilayah DI terluas. Sawah-sawah di Manikin dikelola oleh kelompok tani dengan sistem irigasi permukaan (survace irigation system) primer-sekundertersier dari Bendungan Tilong (Peraturan Menteri). Pengaturan distribusi irigasi dilakukan secara manual dengan cara mengangkat atau memutar pintu air yang yang terbuat dari lempengan besi. Pembagian air dilakukan berdasarkan waktu dan debit air tersedia.

Hasil survei tim PPT ke DI Manikin menunjukkan bahwa pekerjaan buka-tutup pintu air yang masih manual telah menimbulkan persoalan, yaitu ketidakpuasan petani karena lahannya terlambat mendapatkan air, waktu aliran tidak sama ke petak sawah dan terjadi pertengkaran karena faktor kecurigaan. Kondisi ini menyebabkan beberapa pintu air rusak, tanaman tidak berkembang dan menurunnya hasil panen (Laumal F, 2015). Data Juknis Pra Rima Tani tahun 2014 menyebutkan pertumbuhan beras lokal dari Kabupaten Kupang per 31 Desember 2014 hanya berada di bawah $6 \mathrm{t} / \mathrm{ha}$.

Saat ini perkembangan teknologi elektronika, kontrol dan informatika sangat maju di mana banyak dibuat berbagai komponen analog maupun digital berukuran kecil yang mendukung untuk dikombinasikan menjadi sistem kontrol otomatis pengatur irigasi. Komponen elektronika yang tersedia di pasaran dapat ditemukan dalam bentuk mikrokontroler sebagai penyimpan dan pengolah instruksi dan komponen sensor yang compatible dengan mikrokontroler untuk membaca gejala alam. Gejala/nilai perubahan yang terjadi di pintu air yaitu waktu dan debit air menjadi parameter yang dapat ditangkap oleh sensor, diolah untuk kemu- 
dian dieksekusi oleh mikrokontroler menjadi acuan untuk mengoperasikan pintu air. Salah satu spesifikasi mikrokontroler yang dapat dipakai untuk mengembangkan sistem kontrol pintu air adalah ATMEGA328 yang mampu menyimpan serta mengolah data sensor yang terhubung kepadanya. Di samping itu bahasa pemrogram sebagai instruksi membaca dan mengolah data juga bermacam-macam dan kompatibel dengan ATMEGA328 (Hussain et al, 2015).

Dari gambaran pengelolaan pintu air di DI Manikin dan adanya dukungan teknologi mikrokontroler, maka perlu dikembangkan sistem irigasi otomatis berbasis mikrokontroler di DI Manikin untuk membantu petani dalam mengontrol mekanisme penyaluran air pada saluran irigasi di daerah irigasi Manikin agar lebih merata dan adil serta membantu mengurangi aktivitas petugas pintu air irigasi sehingga para petani lebih maksimal bekerja di petak sawah, sehingga persoalan pengelolaan dapat teratasi, pertumbuhan tanaman menjadi lebih baik dan hasil panen kembali meningkat.

\section{B. Metode dan Diagram Riset}

Penelitian ini dilaksanakan di Laboratorium Elektronika, Jurusan Teknik Elektro, Politeknik Negeri Kupang. Metode yang diterapkan dalam penelitian ini adalah metode perancangan dan implementasi dengan waktu pelaksanaan selama 2 tahun. Tahun pertama pengerjaan berfokus pada pengembangan sistem kontrol pintu air yang tahap pengerjaan telah mencapai 80 persen. Pengerjaan yang sudah dilakukan meliputi desain sistem kontrol, pemograman sistem kontrol, desain pintu air dan interkoneksi sistem kontrol dengan pintu air. Pengujian baru dilakukan tahap 1, sedangkan pengujian tahap 2 sekaligus pengambilan data-data pengujian belum dilaksanakan. 


\section{Berikut merupakan gambaran diagram Fishbone dari riset ini :}

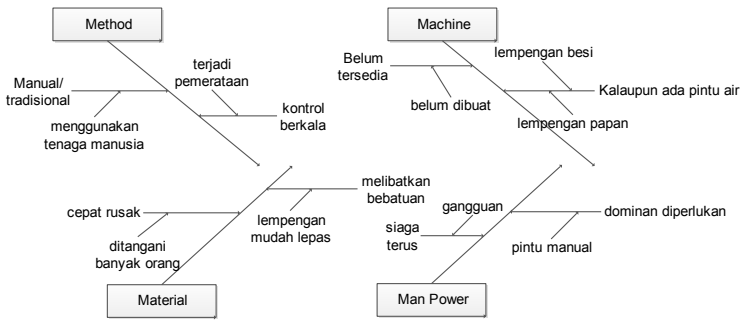

\section{Dari diagram di atas dapat dirumuskan beberapa hal sebagai berikut:}

\begin{tabular}{|c|c|}
\hline & $\begin{array}{l}\text { Saat ini belm tersedianya System Kontrol Air irigasi di sawah yang otomatis, walaupun pada } \\
\text { suatu persawahan yang luas dan berpetak-petak. Hal ini disebabkan karena belum ada } \\
\text { membuatnya. Kalaupun ada system kontrol yang diimplementasikan, baru pada kontrol green } \\
\text { house, lalulintas darat atau sensor aliran air saja. Sedangkan di sawah, hanya digunakan } \\
\text { lempengan besi atau susunan papan yang ditahan dengan bebatuan di dalam air agar tidak } \\
\text { mudah terlepas. }\end{array}$ \\
\hline & $\begin{array}{l}\text { Metode yang diimplementasikan pada sistem buka tutup pintu air di persawahan masih bersifat } \\
\text { manual/tradisional, dimana tenaga manusia yang dibutuhkan untuk memindahkan penutup } \\
\text { atau memutar tuas pembuka air. Penutup tersebut secara bergantian dipindahkan dari satu } \\
\text { saluran ke saluran yang lain. Kegiatan buka tutup/kontrol pintu air ini harus dilakukan secara } \\
\text { berkala dan terus-menerus untuk menghindari ketidakmerataan penyaluran air. Penyaluran } \\
\text { yang tidak merata akan menimbulkan konflik di masyarakat petani. }\end{array}$ \\
\hline & $\begin{array}{l}\text { Karena penutup saluran air irigasi yang menggunakan lempengan besi atau susunan papan } \\
\text { yang ditindih dengan bebatuan, menyebabkan material-material ini mudah rapuh/rusak. } \\
\text { Kerusakan tersebut dikarenakan korosi dengan air atau terkikis dengan material lain yang ikut } \\
\text { terbawa air dalam saluran irigasi. Faktor lain yng dapat menyebabkan kerusakan pada material } \\
\text { penutup air adalah banyak tangan yang terlibat ketika menangani pintu air. Faktor tergesah- } \\
\text { gesah, marah, kecewa, dll petugas air dapat melampiaskan dengan merusak barang. }\end{array}$ \\
\hline & $\begin{array}{l}\text { Tenaga manusia sangat dibutuhkan dalam menangani buka ttup pint drainase. Artinya bahwa } \\
\text { manusia harus dominan ditempatkan untuk pekerjaan ini. Hal ini untuk menghindari adanya } \\
\text { gangguan dari pihak lain yang menyebabkan aliran air tidak merata ke semua lahan sawah. Di } \\
\text { samping itu manusia juga harus selalu siaga menjada dan membuka-tutup pintu air. Ketika } \\
\text { lalai dan air tidak merata maka akan cepat menimbulkan pertikaian antar sesama petai. }\end{array}$ \\
\hline
\end{tabular}

Dengan kondisi di atas maka penanganan yang dilakukan melalui penelitian ini adalah sebagai berikut.

Rancangan Sistem Irigasi Pintar berbasis Mikrokontroler yang dibangun adalah sebagai berikut :

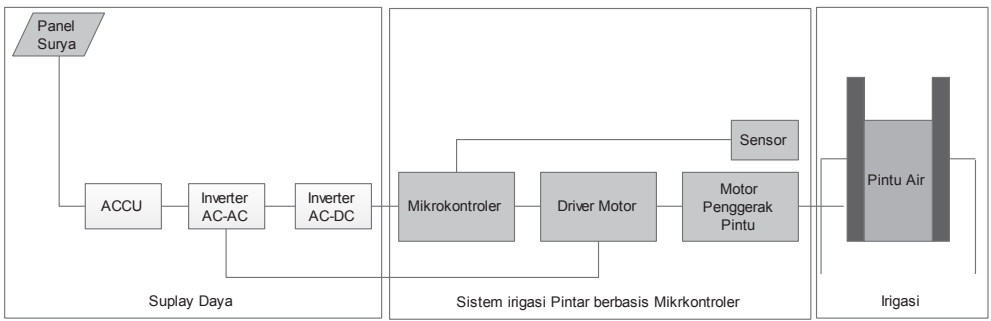


Bagian Suplay Daya adalah sumber listrik yang bersumber dari Sel Surya. Energi matahari akan dikonversi menjadi sumber AC untuk menghidupkan motor listrik dan diubah ke sumber DC untuk digunakan oleh mikrokontroler.

Bagian Sistem Irigasi terdiri dari mikrokontroler sebagai pengontrol sistem, Driver Motor untuk menggerakkan mesin motor yang terhubung ke pintu air. Sedangkan Sensor akan digunakan untuk membaca level/debit air dalam saluran irigasi.

Bagian Irigasi merupakan pintu air yang didesain sedemikian rupa sehingga dapat bergerak mengangkat dan menutup berdasarkan instruksi dari mikrokontroler.

\section{Konsep-Konsep Teoritis}

\section{Definisi Sistem Kontrol}

Sistem kontrol adalah proses pengaturan atau pengendalian terhadap satu atau beberapa besaran (variabel, parameter) sehingga berada pada suatu harga atau dalam suatu kisaran harga (range) tertentu. Di dalam dunia industri, dituntut suatu proses kerja yang aman dan berefisiensi tinggi untuk menghasilkan produk dengan kualitas dan kuantitas yang baik serta dengan waktu yang telah ditentukan. Otomatisasi sangat membantu dalam hal kelancaran operasional, keamanan (investasi, lingkungan), ekonomi (biaya produksi) dan mutu produk.

Ada banyak proses yang harus dilakukan untuk menghasilkan suatu produk sesuai standar, sehingga terdapat parameter yang harus dikontrol yaitu tekanan (pressure), aliran (flow), suhu (temperature), ketinggian (level) dan kerapatan (intensity) Charles dkk, 2011)

Suatu sistem kontrol otomatis dalam suatu proses kerja berfungsi mengendalikan proses tanpa adanya campur tangan manusia (otomatis). Ada dua sistem kontrol pada sistem kontrol otomatis yaitu : 
Open Loop (Loop Terbuka)

Suatu sistem kontrol yang keluarannya tidak berpengaruh terhadap aksi pengontrolan. Dengan demikian pada sistem kontrol ini, nilai keluaran tidak diumpan-balikkan ke parameter pengendalian.

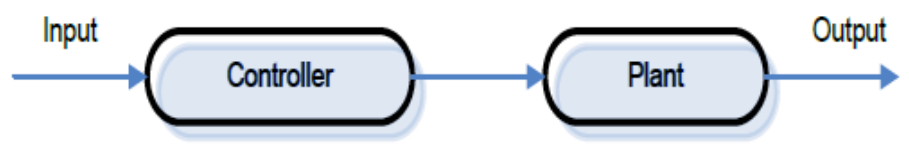

Gambar 1. Diagram Blok Sistem Pengendalian Loop Terbuka.

Close Loop (Loop Tertutup)

Suatu sistem kontrol yang sinyal keluarannya memiliki pengaruh langsung terhadap aksi pengendalian yang dilakukan. Sinyal error yang merupakan selisih dari sinyal masukan dan sinyal umpan balik (feedback), lalu diumpan kepada komponen pengendalian (controller) untuk memperkecil kesalahan sehingga nilai keluaran sistem semakin mendekati harga yang diinginkan.

Keuntungan sistem loop tertutup adalah adanya pemanfaatan nilai umpan balik yang dapat membuat respon sistem kurang peka terhadap gangguan eksternal dan perubahan internal pada parameter sistem. Sedangkan kerugiannya adalah tidak dapat mengambil aksi perbaikan terhadap suatu gangguan sebelum gangguan tersebut mempengaruhi nilai prosesnya.

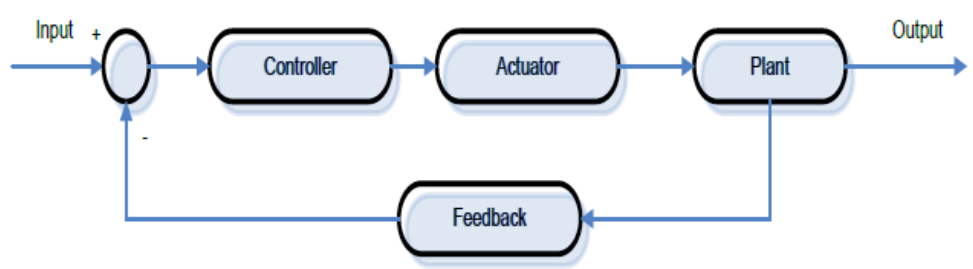

Gambar 2. Diagram Blok Sistem Kontrol Tertutup. 


\section{Jaringan Irigasi}

Menurut Permen PU Nomor 6 Tahun 2012, irigasi adalah usaha penyediaan, pengaturan, dan pembuangan air irigasi untuk menunjang pertanian yang jenisnya meliputi irigasi permukaan, irigasi rawa, irigasi air bawah tanah, irigasi pompa, dan irigasi tambak. Sedangkan Daerah Irigasi adalah kesatuan lahan yang mendapat air dari satu jaringan irigasi. Rahmadan (2003) mendefinisikan irigasi merupakan salah satu sarana pemanfaatan sumber daya air yang berfungsi sebagai penyedia, pengatur dan penyalur air untuk menunjang lahan pertanian.

Jaringan irigasi adalah saluran, bangunan, dan bangunan pelengkapnya yang merupakan satu kesatuan yang diperlukan untuk penyediaan, pembagian, pemberian, penggunaan dan pembuangan air irigasi. Jaringan irigasi terdiri dari petak-petak tersier, sekunder dan primer yang berlainan antara saluran pembawa dan saluran pembuang terdapat juga bangunan utama, bangunan pelengkap, yang dilengkapi keterangan nama luas dan debit.

Petak irigasi adalah petak tanah yang memperoleh air irigasi. Sedangkan kumpulan petak irigasi yang merupakan satu kesatuan yang mendapat air irigasi melalui saluran tersier yang sama disebut petak tersier. Petak tersier menduduki menduduki fungsi sentral, luasnya sekitar 50-100 Ha, kadang-kadang sampai $150 \mathrm{Ha}$. Pemberian air pada petak tersier diserahkan pada petani. Jaringan yang mengalirkan air ke sawah disebut saluran tersier dan kuarter.

Untuk membawa air dari sumbernya hingga ke petak sawah diperlukan saluran pembawa. Saluran-saluran ini terdiri dari saluran primer, sekunder, tersier, dan kuarter. Dengan saluran pembuang, air tidak tergenang pada petak sawah sehingga tidak berakibat buruk. Kelebihan air ditampung dalam suatu saluran pembuang tersier dan kuarter dan selanjutnya dialirkan ke jaringan pembuang 
primer.

Saluran-saluran dapat dilengkapi bermacam-macam bangunan yang berfungsi untuk mempermudah pengaturan air yang berada pada saluran yang lebih kecil atau pada petak sawah.

Pada jaringan irigasi terdapat bangunan-bangunan pelengkap yang terdiri dari :

a. Tanggul-tanggul untuk melindungi daerah irigasi dari banjir. Biasanya dibangun disepanjang tepi sungai sebelah hulu bendung atau sepanjang saluran primer.

b. Kisi-kisi penyaring untuk mencegah tersumbatnya bangunan (pada sipon atau gorong-gorong).

c. Jembatan dan jalan penghubung dari desa untuk keperluan penduduk.

Saluran pembawa adalah saluran yang membawah air irigasi dari bangunan utama ke petak-petak sawah. Ada empat macam saluran pembawa, yaitu saluran primer, sekunder, tersier, dan kuarter.

Selain saluran pembawa, pada daerah irigasi harus terdapat saluran pembuang. Saluran pembuang dibuat untuk menampung buangan (kelebihan) air dari petak sawah. Sistem pembuangan ini disebut sistem drainase. Tujuan sistem drainase adalah mengeringkan sawah, membuang kelebihan air hujan, dan membuang kelebihan air irigasi. Saluran pembuangan di buat di lembah kontur (Anonimous, 2010).

\section{Debit Air}

Debit adalah suatu koefisien yang menyatakan banyaknya air yang mengalir dari suatu sumber persatu-satuan waktu, biasanya diukur dalam satuan $\mathrm{m} 3 /$ detik. Debit aliran dihitung dari rumus :

$$
\mathrm{Q}=\mathrm{V} \times \mathrm{A}
$$

di mana $V=$ kecepatang aliran, dan $\mathrm{A}=$ luas penampang. 
Dengan demikian dalam pengukuran disamping harus mengukur kecepatan aliran, diukur pula luas penampangnya. Distribusi kecepatan untuk tiap bagian pada saluran tidak sama karena tergantung pada bentuk saluran, kekasaran saluran dan kondisi kelurusan saluran. Kecepatan aliran (V) dihitung menggunakan rumus :

$$
V=\frac{1}{n} \cdot R^{2 / 3} \cdot S^{l / 2}
$$

di mana $V=$ kecepatan aliran $(\mathrm{m} / \mathrm{s}), n=$ koefisien Manning, $R=$ jari-jari hidraulik (m), $S=$ kemiringan dasar saluran (Raju K R, 1986).

\section{Pintu Air Irigasi}

Pintu air merupakan struktur dari bendung yang berfungsi untuk mengatur, membuka dan menutup aliran air di saluran. Bagian penting dari pintu air adalah :

a. Daun pintu (gate leaf), adalah bagian dari pintu air yang menahan tekanan air dan dapat digerakkan untuk membuka, mengatur dan menutup aliran air.

b. Rangka pengatur arah gerakan (guide frame), adalah alur dari baja atau besi yang dipasang masuk ke dalam beton yang digunakan untuk menjaga agar gerakan dari daun pintu sesuai dengan yang direncanakan.

c. Angker (anchorage), adalah baja atau besi yang ditanam di dalam beton dan digunakan untuk menahan rangka pengatur arah gerakan agar dapat memindahkan muatan dari pintu air ke dalam konstruksi beton.

d. Hoist, adalah alat untuk menggerakkan daun pintu air agar dapat dibuka dan ditutup dengan mudah (Anonimous, 2010). 

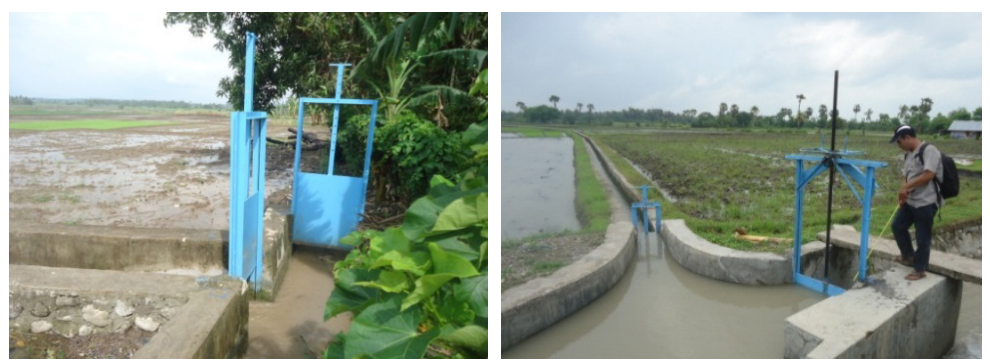

Gambar 3. Pintu Air Irigasi di DI Manikin.

Sumber : Survei tim Laumal F, 2015

\section{ATMega328}

Menurut Haryanto (2008), ATMega328 merupakan mikrokontroler keluarga AVR 8 bit yang memiliki ukuran fisik lebih kecil, namun memori dan periperial lainnya tidak kalah dengan keluarga AVR yang lain.

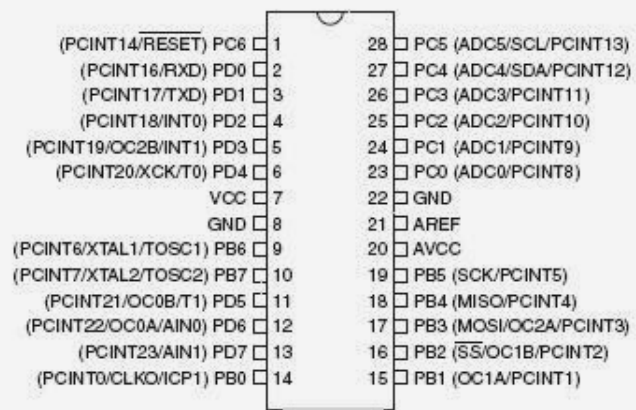

Gamabr 4. Pin Mikrokontroler ATMega328.

ATMega328 memiliki 3 buah PORT utama yaitu PORTB, PORTC, dan PORTD dengan total pin inputloutput sebanyak 23 
pin. PORT tersebut dapat difungsikan sebagai inputloutput digital atau difungsikan sebagai periperal lainnya.

a. Port B

Port $B$ merupakan jalur data 8 bit yang dapat difungsikan sebagai input/output. Selain itu PORT B juga dapat memiliki fungsi alternatif seperti :

1) ICP1 (PB0), berfungsi sebagai Timer Counter 1 input capture pin.

2) OC1A (PB1), OC1B (PB2) dan OC2 (PB3) dapat difungsikan sebagai keluaran PWM (Pulse Width Modulation).

3) MOSI (PB3), MISO (PB4), SCK (PB5), SS (PB2) merupakan jalur komunikasi SPI.

4) Selain itu pin ini juga berfungsi sebagai jalur pemograman serial (ISP).

5) TOSC1 (PB6) dan TOSC2 (PB7) dapat difungsikan sebagai sumber clock external untuk timer.

6) XTAL1 (PB6) dan XTAL2 (PB7) merupakan sumber clock utama mikrokontroler.

b. Port $\mathrm{C}$

Port $C$ merupakan jalur data 7 bit yang dapat difungsikan sebagai inputloutput digital. Fungsi alternatif PORTC antara lain :

1) $\mathrm{ADC6}$ channel (PC0,PC1,PC2,PC3,PC4,PC5) dengan resolusi sebesar 10 bit. ADC dapat digunakan untuk mengubah input yang berupa tegangan analog menjadi data digital

2) I2C (SDA dan SDL) merupakan salah satu fitur yang terdapat pada PORTC. I2C digunakan untuk komunikasi 
dengan sensor atau device lain yang memiliki komunikasi data tipe I2C seperti sensor kompas, accelerometer nunchuck.

c. Port D

Port $D$ merupakan jalur data 8 bit yang masing-masing pin-nya juga dapat difungsikan sebagai input/output. Sama seperti Port $B$ dan Port $C$, Port $D$ juga memiliki fungsi alternatif dibawah ini.

1) USART (TXD dan RXD) merupakan jalur data komunikasi serial dengan level sinyal TTL. Pin TXD berfungsi untuk mengirimkan data serial, sedangkan RXD kebalikannya yaitu sebagai pin yang berfungsi untuk menerima data serial.

2) Interrupt (INT0 dan INT1) merupakan pin dengan fungsi khusus sebagai interupsi hardware. Interupsi biasanya digunakan sebagai selaan dari program, misalkan pada saat program berjalan kemudian terjadi interupsi hardware/software maka program utama akan berhenti dan akan menjalankan program interupsi.

3) XCK dapat difungsikan sebagai sumber clock external untuk USART, atau dapat memanfaatkan clock dari CPU, sehingga tidak perlu membutuhkan external clock.

4) T0 dan T1 berfungsi sebagai masukan counter external untuk timer 1 dan timer 0 .

5) AIN0 dan AIN1 keduanya merupakan masukan input untuk analog comparator.

\section{Fitur AVR ATMega328}

ATMega328 adalah mikrokontroller keluaran dari atmel 
yang mempunyai arsitektur RISC (Reduce Instruction Set Computer) yang dimana setiap proses eksekusi data lebih cepat dari pada arsitektur CISC (Completed Instruction Set Computer). Beberapa fitur ATMEGA328 yaitu :

a. Memiliki 130 macam instruksi yang hampir semuanya dieksekusi dalam satu siklus clock dan 32 x 8-bit register serba guna dengan kecepatan mencapai 16 MIPS dengan clock $16 \mathrm{MHz}$.

b. Memiliki $32 \mathrm{~KB}$ Flash memory, $2 \mathrm{~KB}$ SRAM (Static Random Access Memory) dan 1 KB EEPROM (Electrically Erasable Programmable Read Only Memory) sebagai tempat penyimpanan data semi permanent dan memiliki

c. Memiliki 14 pin I/O digital, 6 diantaranya PWM (Pulse Width Modulation) output.

d. Master / Slave SPI Serial interface.

Mikrokontroller ATmega 328 memiliki arsitektur Harvard, yaitu memisahkan memori untuk kode program dan memori untuk data sehingga dapat memaksimalkan kerja dan parallelism (Wardhana, 2006).

Instruksi - instruksi dalam memori program dieksekusi dalam satu alur tunggal, dimana pada saat satu instruksi dikerjakan instruksi berikutnya sudah diambil dari memori program. Konsep inilah yang memungkinkan instruksi - instruksi dapat dieksekusi dalam setiap satu siklus clock. 32 x 8-bit register serba guna digunakan untuk mendukung operasi pada ALU (Arithmatic Logic unit) yang dapat dilakukan dalam satu siklus. 6 dari register serbaguna ini dapat digunakan sebagai 3 buah register pointer 16-bit pada mode pengalamatan tidak langsung untuk mengambil data pada ruang memori data. Ketiga register pointer 16-bit ini disebut dengan register X (gabungan R26 dan R27), register Y ( gabungan R28 dan 
R29), dan register Z (gabungan R30 dan R31 ). Hampir semua instruksi AVR memiliki format 16-bit. Setiap alamat memori program terdiri dari instruksi 16-bit atau 32-bit.

Selain register serba guna di atas, terdapat register lain yang terpetakan dengan teknik memory mapped I/O selebar 64 byte. Beberapa register ini digunakan untuk fungsi khusus antara lain sebagai register control Timer/ Counter, Interupsi, ADC, USART, SPI, EEPROM, dan fungsi I/O lainnya. Register - register ini menempati memori pada alamat 0x20h - 0x5Fh (Anonimous, 2014).

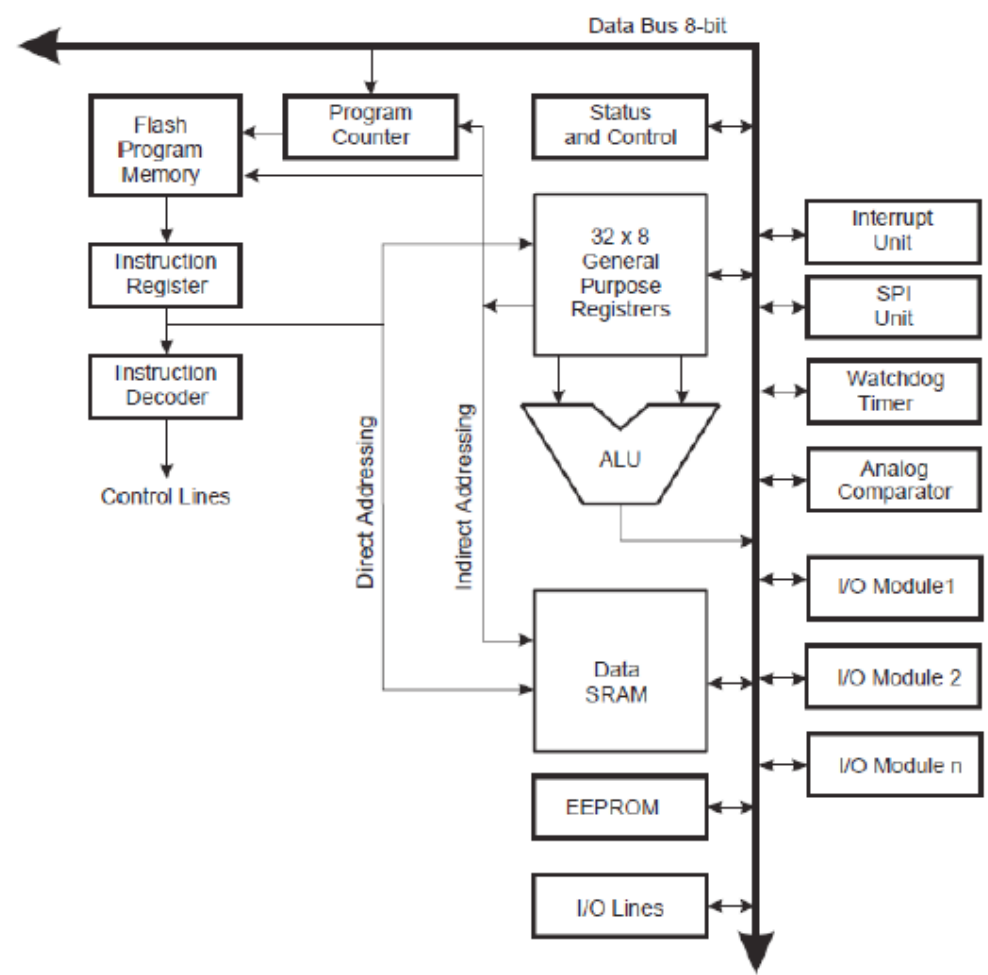

Gambar 5. Tampilan Arsitektur ATMega328. 


\section{Implementasi Teknologi Mikrokontroler Pada Sistem Irigasi}

1. Desain Pintu Air Irigasi Pintar Berbasis ATMega328

Terdapat 2 bagian pada rancangan pintu air irigasi pintar, yaitu bagian kontrol dan bagian pintu air, sebagaimana pada Gambar 6 berikut ini.

\section{BAGIAN KONTROL}

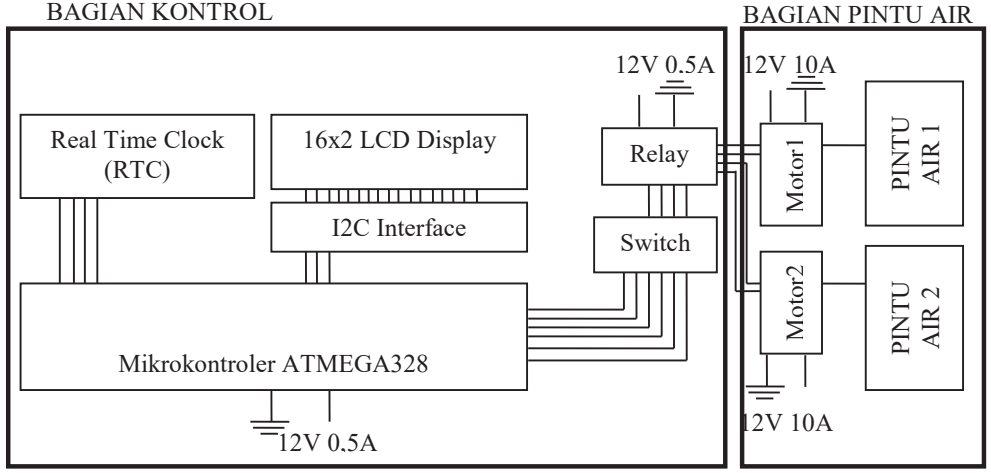

(a)



(b)

Gambar 6. Diagram Hardware Sistem Kontrol Pintu Air Irigasi (a) Skema Rancangan (b) Interkoneksi komponen sistem kontrol dan Pintu Air Irigasi 
Bagian kontrol tersusun dari Mikrokontroler ATMEGA328 yang tertanam pada minimum sistem ARDUINO dan berfungsi sebagai central processing bagi pengolahan data komponen sensor yang terhubung kepadanya. Sensor RTC bertugas memberikan data waktu secara realtime dan mengirim ke Atmega328. Data realtime waktu digunakan Atmega328 untuk membuat jadwal pengoperasian motor1 dan motor2 pada bagian pintu air. Limit switch berfungsi memutuskan arus yang mengalir menuju relay ketika plat pintu air bergerak dan menyentuh kepadanya. Sedangkan 16x2 LCD display berfungsi menampilkan informasi waktu dan status aktivitas pintu air. Atmega328 menggunakan sumber tegangan DC $9-12$ volt, sedangkan komponen sensor dan relay memanfaatkan tegangan dari pin Vin dan pin 5 volt pada Atmega328.

Pada bagian pintu air, terdiri dari motor DC dua arah $12 \mathrm{~V}$ $10 \mathrm{~A}$ dan pintu air irigasi. Sumber tegangan untuk putaran motor DC diambil dari batery $12 \mathrm{~V}$, sedangkan data putaran diterima dari relay. Mekanik pintu air terbuat dari bahan besi berukuran $60 \times 100$ $\mathrm{cm}$ sedangkan penahan air irigasi terbuat dari plat besi 3 ". Motor berputar kiri atau putar kanan setelah menerima data dari relay. Ketika motor berputar ke kiri, mengangkat plat pintu air dan ketika motor bergerak ke kanan menutup plat pintu air.

\section{Interkoneksi Pintu Air Irigasi Pintar Berbasis ATMega328}

Susunan interkoneksi hardware sistem kontrol Pintu Air Irigasi pintar berbasis Atmega328 ditunjukkan pada gambar 7 berikut. 


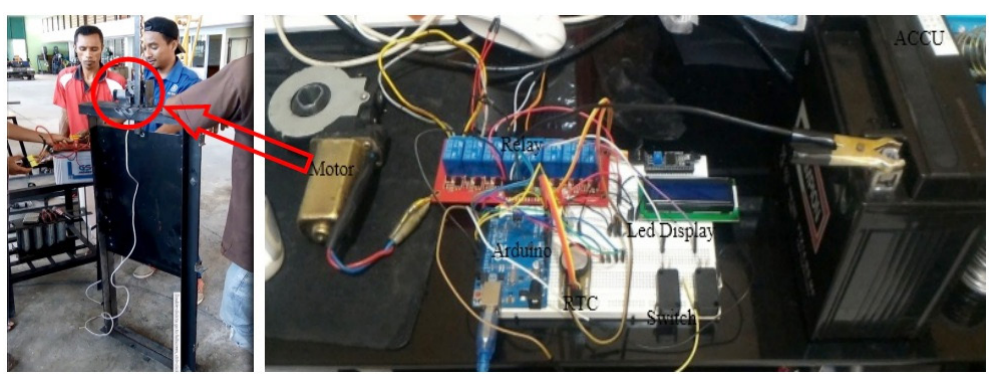

Gambar 7. Interkoneksi Pintu Air Irigasi Pintar

Gambar 7 menampilkan interkoneksi bagian kontrol dari sistem untuk menggerakkan pintu air irigasi. Komponen kontrol yang digunakan dalam sistem yaitu Arduino UNO dengan Atmega328 yang tertanam didalamnya, Realtime clock (RTC) DS1302 5 volt dengan batetry backup 3 volt, 20x4 LCD display dengan koneksi I2C, relay 4 channel 5V DC output 250 VA dan 2 buah LED M1 dan M2. RTC memiliki 5 pin Output yaitu Vcc, GnD, Clk, Dat, Rst. Interkoneksi RTC dengan Atmega328 yaitu:

Pin RTC Pin Arduino (Atmega328)

Vcc $5 \mathrm{~V}$

Gnd Gnd

Clk A0

Dat A1

Rst A2

Relay 4 channel memiliki 6 pin I/O yaitu Vin, Gnd, In1, In2, In3, In4 dengan interkoneksi ke Atmega328 yaitu:

Pin Relay 4 channals Pin Arduino (Atmega328)

Vin

Gnd

In 1

In2
Vin

Gnd

6 melalui limit switch

7 melalui limit switch 
8 melalui limit switch

In 4 9 melalui limit switch

Sedangkan 2 led masing-masing terkoneksi ke pin 10 dan pin 11 Arduino, limit switch 2 pasang (LS1, LS2, Ls3, LS4) berfungsi sebagai pemutus arus antara Arduino dengan relay dengan koneksi sebagai berikut.

Arduinolimit switch Relay

6 LS1 (NC, Common) In 1 7 LS2 (NC, Common) In 2 8

9 LS3 (NC, Common) In3 LS4 (NC, Common) In 4

Bagian pintu air, meliputi rangka pintu besi ukuran 100 x 80 $\mathrm{cm}$, plat besi yang dapat digerakkan ke atas dan ke bawah menggunakan rantai sebagai pengikat yang terhubung pada sebatang besi di bagian tengah. Pada bagian atas rangka ditempatkan motor DC 2 arah 10 ampere 12 volt tersambung ke rantai melalui gir. Limit switch ditempatkan pada bagian atas rangka pintu air sehingga ketika plat pintu bergerak naik atau turun, plat tersebut menyentuh limit switch dan memutuskan arus dari Arduino ke relay.

Interkoneksi komponen pada pintu dengan Sistem Kontrol Atmega328 (Arduino) yaitu:

Motor DC Relay Letak

M1-IN1 R1, Com 1 Pintu Air1

M2-IN2 R2, Com2 Pintu Air1 M3-IN3 R3, Com3 Pintu Air2 M4-IN4 R4, Com 4 Pintu Air2

Limit switch berfungsi memutuskan arus yang masuk ke masing-masing relay ketika putaran motor sudah sampai pada posisi yang diinginkan. Hal ini diperuntukkan bagi pergerakkan pintu air 
ke atas dan ke bawah. Ketika putaran ke atas sudah maksimal sampai ke pembatas, maka lempengan pintu air akan menyentui limit switch dan menghentikan fungsi relay sementara. Jika relay yang lain sudah aktif menggerakkan pintu ke bawah, maka yang sedang tidak aktif secara ototmatis akan aktif kembali. Sebagai indikator berfungsinya motor 1 dan motor2, sistem juga menyediakan 2 buah led (merah dan kuning). Jika led ON menandakan motor sedang aktif (putar kiri atau putar kanan), jika led OFF menandakan motor sedang tidak aktif.

\section{Pemrograman Sistem Kontrol}

Seluruh proses pengolahan data dalam sistem kontrol dilakukan pada central processing (ATMEGA328). Proses pengolahan terdiri dari perintah menggerakkan motor ke kiri atau ke kanan, menyalakan led dan menampilkan aktivitas yang sedang berlangsung kepada user berdasarkan waktu $(\mathrm{t})$ yang diberikan dari Real Time Clock. Rancangan algoritma sistem kontrol pintu air irigasi ditunjukkan pada Gambar 8 berikut.

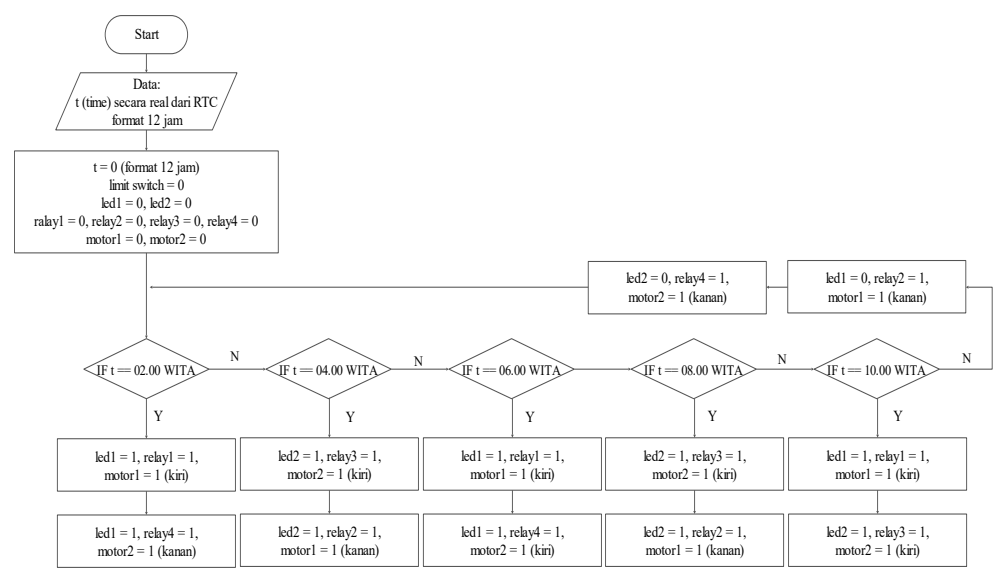

Gambar 8. Rancangan Algoritma Sistem Kontrol Pintu Air 
Pada Gambar 8, sistem kontrol bekerja berdasarkan waktu (t) yang diterima dari Real Time Clock yang disetting dalam format 12 jam, dimulai dari 00.00 AM. Pada kondisi awal, limit switch, led, relay dan motor berada dalam posisi 0 ketika RTC bekerja. Ketika sistem pintu air diaktifkan pada jam 00.00, tidak ada proses yang dilakukan oleh mikrokontroler untuk memutar motor 1 dan motor2. Sistem akan bekerja ketika RTC menunjukkan jam 02.00. Ketika RTC menunjukkan jam 02.00 (sesuai pengaturan di RTC), maka mikrokontroler memberi perintah kepada relay 1 untuk mentriger motor1 untuk berputar ke kiri. Putaran ke kiri kemudian menggerakkan gir yang tersambung ke rantai sehingga rantai akan mengangkat plat pintu air 1 membuka ke atas. Putaran motor 1 akan terhenti ketika plat pintu air 1 menyentuh limit switch (limit switch $=0$ ). Ketika pintu air 1 terbuka, air akan mengalir melalui saluran 1. Terdapat delay sekitar 3 detik setelah pintu air 1 terbuka dan dilanjutkan mikrokontroler memberikna perintah kepada relay 4 untuk mentriger motor 2 untuk berputar ke kanan, yang berarti pintu air 2 bergerak menutup saluran 2. Dalam kondisi ini , LED1 (merah) aktif $(\mathrm{ON})$ menandakan pintu air 1 sedang bekerja dan di LCD akan menampilkan informasi pintu yang sedang terbuka. Pemograman yang dirancang adalah sebagai berikut.






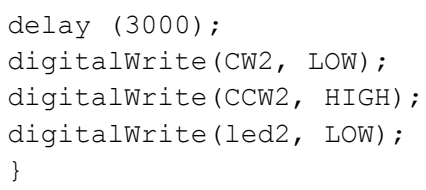

Ketika RTC menunjukkan jam 04.00 (sesuai pengaturan di RTC), maka mikrokontroler memberi perintah kepada relay 2 untuk mentriger motorl untuk berputar ke kanan. Putaran ke kanan kemudian menggerakkan gir yang tersambung ke rantai sehingga rantai akan menurunkan plat pintu air 1 menutupi saluran air. Putaran motor 1 akan terhenti ketika plat pintu air 1 menyentuh limit switch (limit switch $=0$ ). Terdapat delay sekitar 3 detik setelah pintu air 1 tertutup dan dilanjutkan mikrokontroler memberikan perintah kepada relay 3 untuk mentriger motor 2 untuk berputar ke kiri, yang berarti pintu air 2 bergerak membuka. Dalam kondisi ini, LED2 (hijau) akan ON menandakan pintu air 2 sedang bekerja dan di LCD akan menampilkan informasi pintu yang sedang terbuka. Pemograman yang dirancang adalah sebagai berikut.

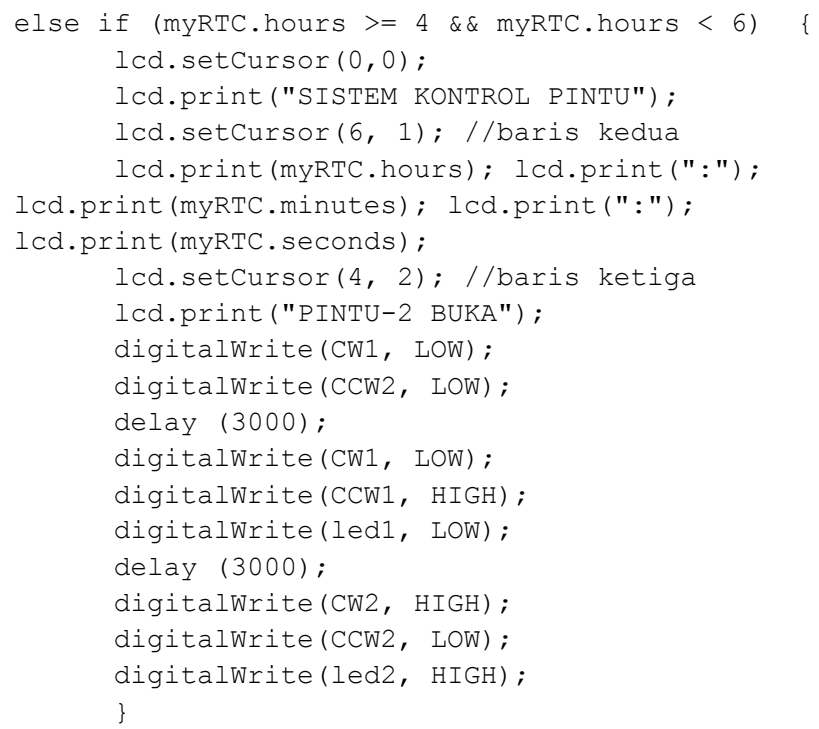


Ketika RTC menunjukkan jam 06.00 (sesuai pengaturan di RTC), maka mikrokontroler memberi perintah kepada relay 1 untuk mentriger motorl untuk berputar ke kiri. Putaran ke kiri kemudian menggerakkan gir yang tersambung ke rantai sehingga rantai akan mengangkat plat pintu air 1 membuka ke atas. Putaran motor 1 akan terhenti ketika plat pintu air 1 menyentuh limit switch (limit switch $=0$ ). Ketika pintu air 1 terbuka, air akan mengalir melalui saluran 1. Terdapat delay sekitar 3 detik setelah pintu air 1 terbuka dan dilanjutkan mikrokontroler memberikan perintah kepada relay 4 untuk mentriger motor 2 untuk berputar ke kanan, yang berarti pintu air 2 bergerak menutup saluran 2. Dalam kondisi ini , LED1 (merah) aktif $(\mathrm{ON})$ menandakan pintu air 1 sedang bekerja dan di LCD akan menampilkan informasi pintu yang sedang terbuka. Pemograman yang dirancang adalah sebagai berikut.

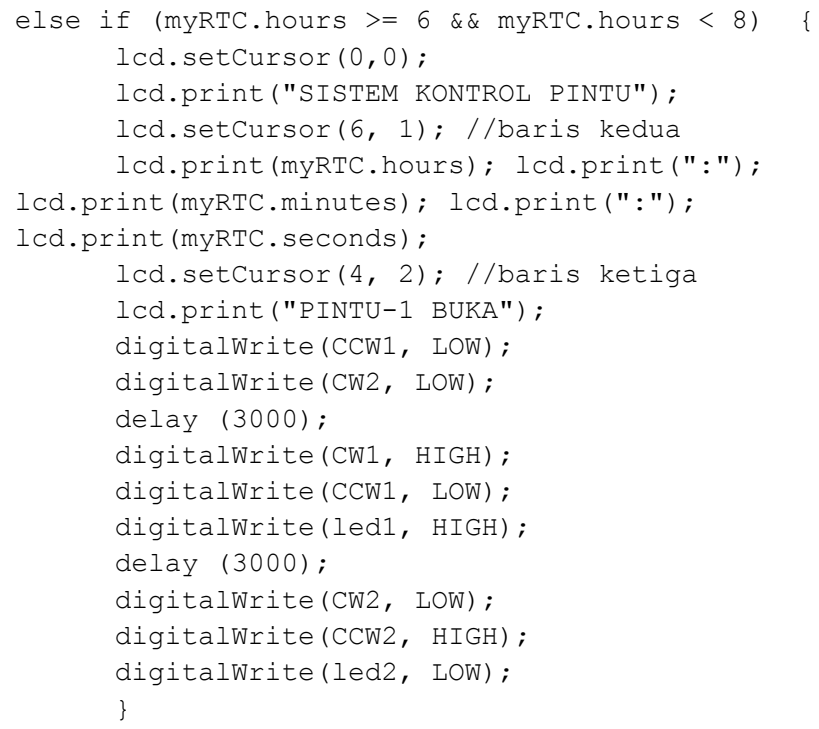


Ketika RTC menunjukkan jam 08.00 (sesuai pengaturan di RTC), maka mikrokontroler memberi perintah kepada relay 2 untuk mentriger motor1 untuk berputar ke kanan. Putaran ke kanan kemudian menggerakkan gir yang tersambung ke rantai sehingga rantai akan menurunkan plat pintu air 1 menutupi saluran air. Putaran motor 1 akan terhenti ketika plat pintu air 1 menyentuh limit switch (limit switch $=0$ ). Terdapat delay sekitar 3 detik setelah pintu air 1 tertutup dan dilanjutkan mikrokontroler memberikan perintah kepada relay 3 untuk mentriger motor 2 untuk berputar ke kiri, yang berarti pintu air 2 bergerak membuka. Dalam kondisi ini , LED2 (hijau) akan ON menandakan pintu air 2 sedang bekerja dan di LCD akan menampilkan informasi pintu yang sedang terbuka. Pemograman yang dirancang adalah sebagai berikut.

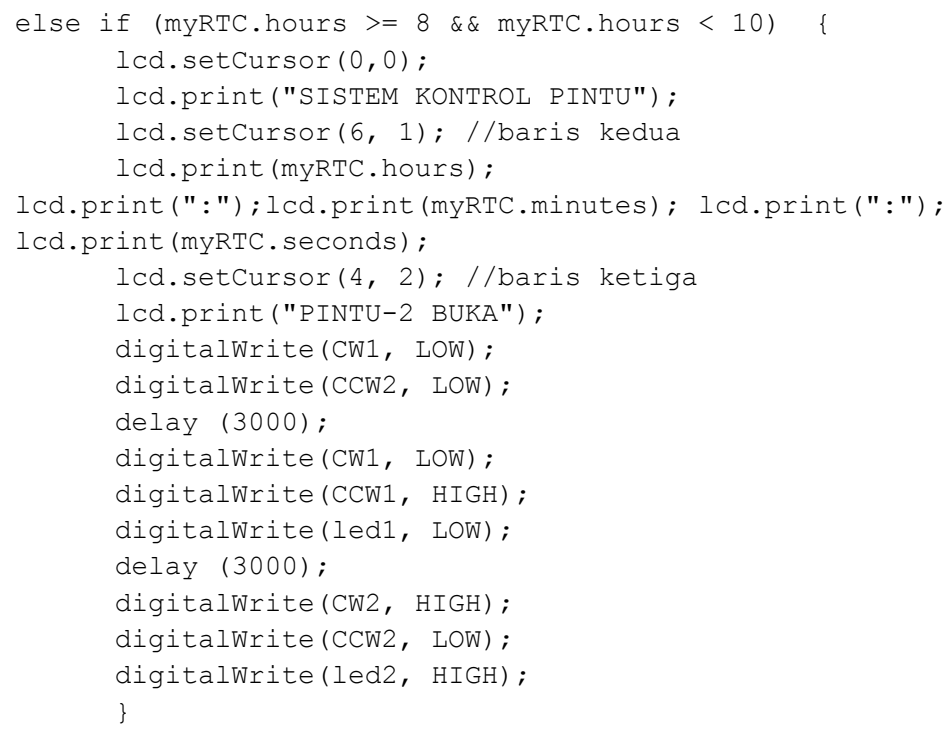


Ketika RTC menunjukkan jam 00.00 (sesuai pengaturan di RTC), maka mikrokontroler memberi perintah kepada relay 2 untuk mentriger motorl untuk berputar ke kanan. Putaran ke kanan menggerakkan gir yang tersambung ke rantai sehingga rantai akan menurunkan plat pintu air 1 menutupi saluran air 1 . Putaran motor 1 akan terhenti ketika plat pintu air 1 menyentuh limit switch (limit switch =0). Terdapat delay sekitar 3 detik setelah pintu air 1 terbuka dan dilanjutkan mikrokontroler memberikan perintah kepada relay 4 untuk mentriger motor 2 untuk berputar ke kanan, yang berarti pintu air 2 juga akan tertutup. Dalam kondisi ini , LED1 (merah) dan LED2 (kuning) OFF menandakan pintu air 1 dan pintu air 2 tidak bekerja dan LCD akan menampilkan informasi.

\section{Pengujian dan Hasil}

Setelah pemograman selesai, dilakukan simulasi untuk memastikan apakah pintu air irigasi pintar bekerja atau tidak. Simulasi dilakukan di laboratorium Teknik Mesin menggunakan satu pintu air. Langkah awal adalah menghubungkan 2 kabel dari motor DC pada pintu ke relay1 dan relay2, dilanjutkan dengan menghubungkan 2 pasang kabel dari limit switch1 dan limit switch2 ke relay dan mikrokontroler Atmega328. Suplay daya ke motor DC dan relay menggunakan Baterry 12 Volt $10 \mathrm{~A}$, sedangkan untuk mikrokontroler Atmega328 (Arduino) menggunakan charger $9 \mathrm{~V}$ $1000 \mathrm{~mA}$.

Karena sistem kontrol disetting pada jam 00.00, maka sistem ON dengan start awal pada jam 00.00 dalam kondisi pintu air irigasi berada dalam posisi tertutup (OFF) atau tidak ada arus yang mengalir ke motor untuk mengerakannya. Setelah 2 jam (pada pukul 02.00) berdasarkan rekomendasi waktu dari RTC, mikrokontroler 
memerintahkan relayl untuk terbuka, menggerakkan motor1 ke kiri dan mengangkat plat pintu air irigasi. Hasil simulasi ini dan tambahan 2 jam berikutnya ditampilkan pada Tabel 1 .

Tabel 1. Simulasi pengoperasian pintu air irigasi pintar berbasis Atmega328

\begin{tabular}{|c|c|c|c|c|c|}
\hline \multirow{2}{*}{ Waktu } & LED & Relay & \multirow{2}{*}{ Motor1 } & \multicolumn{2}{|l|}{ Pintu } \\
\hline & L1 L2 & R1 R2 R3 R4 & & P1 & P2 \\
\hline $00.00-02.00$ & off off & off off off off & Putar kanan & tutup & tutup \\
\hline 02.00-04.00 & on off & on off off on & putar kiri & buka & tutup \\
\hline 04.00-06.00 & off on & off on on off & putar kanan & tutup & buka \\
\hline 06.00-08.00 & on off & on off off on & putar kiri & buka & tutup \\
\hline $08.00-10.00$ & off on & off on on off & putar kanan & tutup & buka \\
\hline $10.00-00.00$ & on on & on off on off & putar kiri & buka & buka \\
\hline
\end{tabular}

Dari Tabel 1 terlihat bahwa pada pukul 00 s/d 02, Led merah dan kuning berstatus OFF, tidak ada arus yang mengalir ke relay (R1 s/d R4), kondisi motor pada posisi sudah berputar ke kanan yang artinya pintu1 dan pintu air 2 berstatus OFF (tutup). Ketika RTC menunjukkan pukul 02.00, Led merah $\mathrm{ON}$, ada arus yang mengalir ke Relay1 dan Relay4, namun pintu air 2 tetap berada pada posisi tertutup karena status limit switch3 = 0 atau plat menyentuh limit switch 3 dan memutuskan arus ke motor2. Sedangkan R1 akan aktif, memutar motor1 ke kiri sehingga mengangkat plat pintu air 1 (terbuka).

Ketika RTC menunjukkan pukul 04.00, Led kuning ON, ada arus yang mengalir ke Relay2 dan Relay3, pintu air 1 bergerak menutup hingga status limit switch2 $=0$ atau plat menyentuh limit switch 2 dan memutuskan arus ke motor1. Sedangkan R3 akan aktif, memutar motor2 ke kiri sehingga mengangkat plat pintu air 2 (terbuka). Ketika RTC $=06.00$ sistem akan beroperasi sama seperti saat RTC $=02.00$. Demikian pula ketika $\mathrm{RTC}=08.00$, 
sistem beroperasi seperti ketika RTC $=04.00$. Ketika RTC $=10.00$ Led merah dan led kuning berstatus ON, R1 dan R3 aktif, motor1 putar kiri dan dan membuka pintu air 1, sedangkan R4 tetap berada pada status ON. Artinya pada pukul 10.00 s/d 00.00 pintu air 1 dan pintu air 2 berada pada posisi terbuka, pukul $00.00 \mathrm{~s} / \mathrm{d}$ 02.00 R2 dan R4 aktif, memutar motor 1 dan motor 2 ke kanan dan menutup pintu.

Terdapat 2 pintu air yang simulasikan untuk sistem buka dan tutupnya. Masing-masing pintu diindikasi oleh 2 led yang terdiri dari LED Merah untuk pintu air pertama dan LED Kuning untuk pintu air kedua. Led merah membaca status data dari pin 7 dan pin 8, sedangkan led kuning membaca status data di pin 9 dan 10 . Ketika pin 7 bernilai 1 (HIGH) dan pin 8 bernilai 0 (LOW), maka Led Merah ON dan berarti pintu air satu terbuka, sedangkan ketika pin 9 bernilai 1 (HIGH) dan pin 10 bernilai 0 (LOW), maka led kuning $\mathrm{ON}$ dan berarti pintu air 2 yang terbuka. Secara lengkap pengujian operasi buka tutup pintu air irigasi diberikan pada Tabel 2 berikut.

Tabel 2. Pengujian waktu RTC terhadap perilaku port di Atmega328 Arduino.

\begin{tabular}{|c|c|c|c|}
\hline \multirow{3}{*}{ Jam } & \multirow{3}{*}{ Port Arduino } & \multicolumn{2}{|c|}{ Indikator Led } \\
\hline & & Led & Led \\
\hline & & Merah & Kuning \\
\hline $00 \mathrm{~s} / \mathrm{d} 02$ & Port $6=0$, port $7=1$, port $8=0$, port $9=1$ & OFF & OFF \\
\hline $02 \mathrm{~s} / \mathrm{d} 04$ & Port $6=1$, port $7=0$, port $8=0$, port $9=1$ & ON & OFF \\
\hline $04 \mathrm{~s} / \mathrm{d} 06$ & Port $6=0$, port $7=1$, port $8=1$, port $9=0$ & OFF & ON \\
\hline $06 \mathrm{~s} / \mathrm{d} 08$ & Port $6=1$, port $7=0$, port $8=0$, port $9=1$ & $\mathrm{ON}$ & OFF \\
\hline $08 \mathrm{~s} / \mathrm{d} 10$ & Port $6=0$, port $7=1$, port $8=1$, port $9=0$ & OFF & ON \\
\hline $10 \mathrm{~s} / \mathrm{d} 00$ & Port $6=1$, port $7=0$, port $8=1$, port $9=0$ & ON & ON \\
\hline
\end{tabular}

Pada Tabel 2 menunjukkan bahwa Led Merah ON ketika port 6, 7, 8, 9 bernilai 1001, 1010, sedangkan Led Kuning ON 
pada nilai 0110, 1010. Led merah ON menunjukkan bahwa pintu air 1 yang sedang bekerja (menutup/terbuka) dan led kuning $\mathrm{ON}$ menunjukkan pintu air 2 yang bekerja (menutup/membuka).

Ketika sistem ON, besar tegangan yang bekerja pada sistem kontrol pintu air adalah 9 volt 4,5 A, sedangkan pada motor DC terpasang besar tegangan terpakai sebesar 12 volt. Ketika sistem bekerja arus listrik yang mengalir melewati pin-pin output mikrokontroler adalah sebesar 2.7 ampere, sebagaimana pada Tabel 3.

Tabel 3. Pengujian Arus pada masing-masing Relay berdasarkan waktu yang ditentukan

\begin{tabular}{lllll}
\hline Jam & \multicolumn{4}{l}{ Besar Arus terukur (ampere) } \\
\hline & 6 & 7 & 8 & 9 \\
\hline $02 \mathrm{~s} / \mathrm{d} 04$ & $2.76 \mathrm{~A}$ & $0 \mathrm{~A}$ & $0 \mathrm{~A}$ & $2.76 \mathrm{~A}$ \\
$04 \mathrm{~s} / \mathrm{d} 06$ & $0 \mathrm{~A}$ & $2.76 \mathrm{~A}$ & $2.76 \mathrm{~A}$ & $0 \mathrm{~A}$ \\
$06 \mathrm{~s} / \mathrm{d} 08$ & $2.76 \mathrm{~A}$ & $0 \mathrm{~A}$ & $0 \mathrm{~A}$ & $2.76 \mathrm{~A}$ \\
$08 \mathrm{~s} / \mathrm{d} 10$ & $0 \mathrm{~A}$ & $2.76 \mathrm{~A}$ & $2.76 \mathrm{~A}$ & $0 \mathrm{~A}$ \\
$10 \mathrm{~s} / \mathrm{d} 12$ & $2.76 \mathrm{~A}$ & $0 \mathrm{~A}$ & $0 \mathrm{~A}$ & $2.76 \mathrm{~A}$ \\
$12 \mathrm{~s} / \mathrm{d} 02$ & $0 \mathrm{~A}$ & $2.76 \mathrm{~A}$ & $0 \mathrm{~A}$ & $2.76 \mathrm{~A}$ \\
\hline
\end{tabular}

Dari Tabel 3 menunjukkan bahwa ketika waktu (t) menunjukkan jam 2 s/d jam 4, pin pin 6 dan pin 9 terjadi aliran aurs sebebsar 2.7 A masing-masing menuju ke motor 1 untuk menggerakkan ke kiri dan ke motor 2 untuk menggerakkan ke kanan. Pada pin yang lain tidak terjadi aliran arus. 


\section{2}

\section{Pengembangan sensor getar berbasis mikrokontroler untuk monitoring getaran mesin bubut horisontal}

\section{A. Deskripsi Permasalahan}

Perkembangan teknologi komunikasi saat ini sudah sangat pesat seiring dengan kemajuan jaman dan meningkatnya kebutuhan manusia. Pemikiran manusia yang selalu berupaya untuk memanfaatkan sumber daya dengan efisien membuat inovasi dan perkembangan teknologi pun terus berkembang. Pemanfaatan teknologi yang dikembangkan dengan berbagai dasar ilmu pengetahuan telah menyebabkan perubahan serta peralihan teknologi yang pada akhirnya memudahkan manusia dalam menyelesaikan banyak persoalannya. Teknologi komunikasi merupakan contoh salah satu bidang teknologi peralihan yang juga ikut berkembang, karena sistem komunikasi tidak lagi mengenal batas dan waktu serta telah dimungkinkan untuk dilakukan secara nirkabel baik dalam transmisi data audio maupun video. 
Komunikasi nirkabel dapat diimplementasikan pada banyak obyek tidak bergerak, misalnya komputer dengan komputer, komputer dengan peralatan elektronik, sesama peralatan elektronik atau mesin-mesin tertentu yang dimaksudkan untuk me-monitoring dan menganalisa komponen mesin itu. Komponen yang dianalisa beberapa di antaranya berhubungan dengan perawatan/ maintenance (umur komponen, lama pakai komponen). Semua ini dapat di-monitoring menggunakan jaringan kabel maupun nirkabel (wireless). Salah satu perilaku benda yang dapat di-monitoring adalah getaran. Getaran yang ditimbulkan oleh benda; misalnya mesin, dapat di-monitoring secara visual dengan memanfaatkan kombinasi mikrokontroler dan bahasa pemrograman untuk mendapatkan sebuah aplikasi. Monitoring dapat dilakukan secara berkala (sesuai permintaan) dan real time (selama mesin bekerja/menghasilkan getaran).

Mesin bubut horizontal adalah salah satu mesin listrik di Laboratorium Teknik Mesin Politeknik Negeri Kupang yang selalu digunakan untuk kegiatan praktik mahasiswa. Dengan rutinitas penggunaan yang cukup tersebut, memberikan perubahan-perubahan yang menyimpang dari karakteristik ideal mesin. Perubahan ini biasanya diantisipasi dengan melakukan perawatan secara berkala sesuai dengan SOP (Standar Operasional Prosedur) yang sudah disiapkan oleh teknisi laboratorium atau manual book, sehingga perawatan atau penggantian komponen yang rusak akan dilakukan bila komponen tersebut telah benar-benar rusak atau secara visual dirasakan bahwa komponen tersebut memang sudah layak untuk diganti.

Akan tetapi dengan memanfaatkan teknologi mikrokontroler dan sensor yang diprogram dan dilekatkan pada mesin bubut, getaran mesin yang real time dapat di-monitoring. Informasi 
getaran selanjutnya diolah dan hasilnya dijadikan petunjuk untuk menentukan bilamana perawatan terhadap mesin dapat dilakukan, termasuk penggantian komponen mesin yang telah aus. Untuk mencapai tujuan tersebut, kemudian dibuat rancangan riset yang secara lebih spesifik dimaksudkan untuk merancang sensor getar berbasis mikrokontroler, kemudian untuk melakukan kalibrasi terhadap sensor getar berbasis mikrokontroler agar dapat dimanfaatkan untuk monitoring getaran mesin bubut horizontal, serta untuk menentukan nilai ideal sensor getar terhadap getaran mesin bubut horizontal.

\section{B. Metode dan Diagram Riset}

Berikut merupakan gambaran diagram Fishbone dari riset ini:

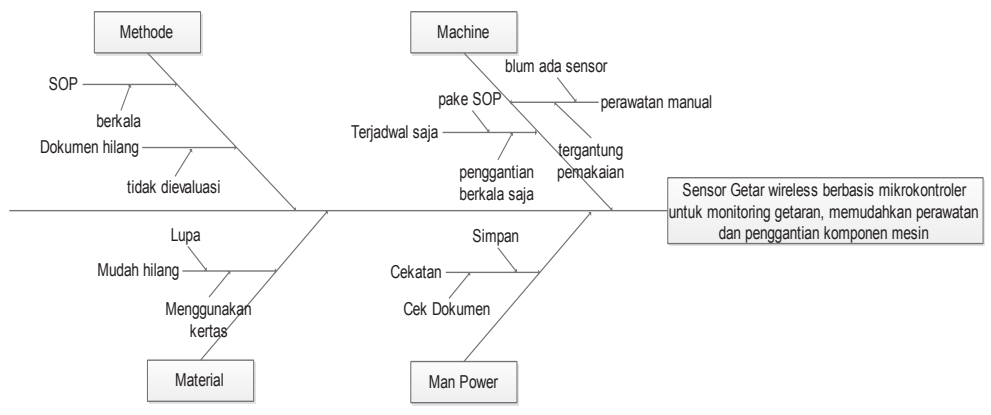

Dari diagram di atas dapat dirangkum beberapa hal sebagai berikut : 


\begin{tabular}{|c|c|}
\hline Machine & $\begin{array}{l}\text { Sistem kontrol perawatan mesin bubut di Labora- } \\
\text { torium Teknik Mesin PNK masih dilakukan dengan } \\
\text { cara manual dan tergantung kepada pemakaian } \\
\text { pada saat praktek. Di samping itu kontrol otomatis } \\
\text { menggunakan sensor juga belum ada sehingga } \\
\text { perawatan hanya berdasarkan waktu yang ditentu- } \\
\text { kan saja. Ketika pemakaianya banyak, maka perawa- } \\
\text { tan dilakukan lebih sering. Tetapi ketika pema- } \\
\text { kaian jarang, perawatan juga jarang dilakukan. } \\
\text { Penggnatian komponen juga dilakukan hanya ketika } \\
\text { usia komponen sudah terlihat aus. }\end{array}$ \\
\hline Method & $\begin{array}{l}\text { Metode kontrol mesin bubut horisontal dilakukan } \\
\text { berdasarkan SOP yang berlaku sehingga perawatan } \\
\text { hanya dilakukan ketika waktu perawatan terjadwal } \\
\text { dijumpai. Jika jadwal belum sampai, perawatan tidak } \\
\text { dilakukan. Pengarsipan dokumen perawatan juga } \\
\text { lebih mudah hilang karena menggunakan lembaran } \\
\text { kertas dan disimpan. Jika lupa, dokumen tersebut } \\
\text { akan hilang begitu saja. }\end{array}$ \\
\hline Material & $\begin{array}{l}\text { Material untuk kontrol perawatan mesin bubut hori- } \\
\text { sontal meggunakan lembaran kertas sehingga akan } \\
\text { mudah hilang, rusak atau terbakar. Petugas yang } \\
\text { sering lupa juga akan menyebabkan dokumentasi } \\
\text { lembaran perawatan menjadi tidak terkontrol. } \\
\text { Akibatnya walaupun ada DOP tetapi perawatan } \\
\text { mesin menjadi terganggu. }\end{array}$ \\
\hline
\end{tabular}




\begin{tabular}{|l|l|}
\hline Man Power & $\begin{array}{l}\text { Dengan sistem kontrol mesin bubut secara manual, } \\
\text { menyebabkan fungsi petugas/teknisi juga harus } \\
\text { cekatan. Baik dalam hal melakukan kontrol } \\
\text { terhadap jadwa perawatan dan dokumen pengisian } \\
\text { pelaksanaan kontrol, maupun terhadap dokumsn } \\
\text { hasil pemeriksaan yang disimpan. }\end{array}$ \\
\hline
\end{tabular}

Penelitian ini dilaksanakan secara ekperimen dengan prosedur sebagai berikut.

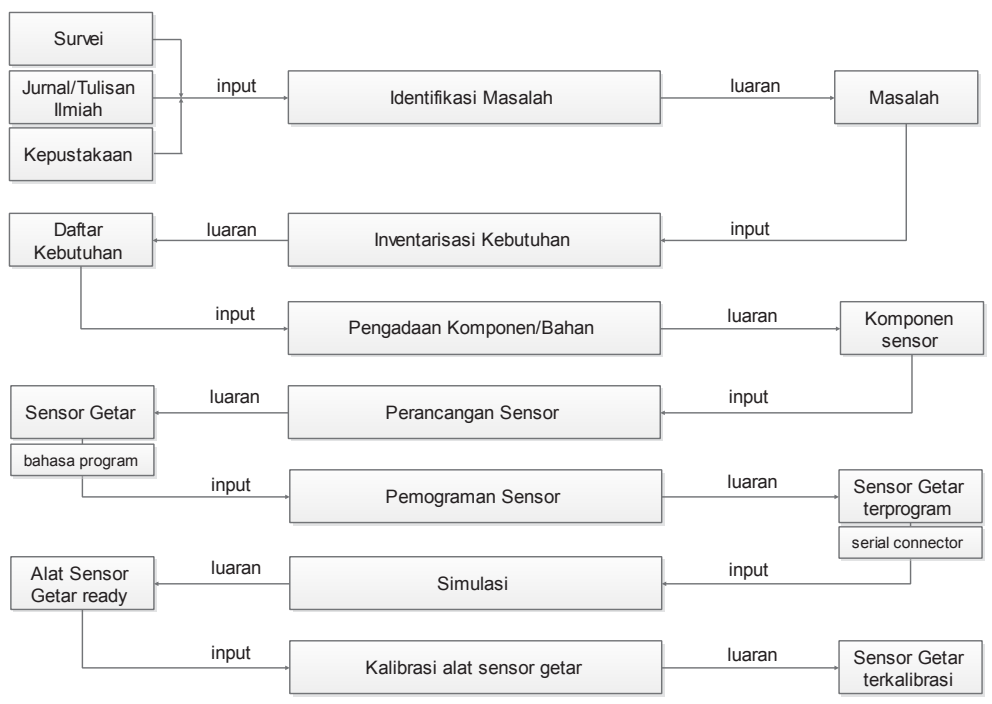

\section{Konsep-Konsep Teoritis}

\section{Sensor Network}

Sensor network adalah sebuah jaringan komunikasi sensor untuk memonitor kondisi fisis atau kondisi lingkungan tertentu pada lokasi yang berbeda antara sensor dan pemrosesan datanya. Pada dasarnya jaringan komunikasi sensor ini digunakan pada 
industri ataupun aplikasi komersial lain baik yang menggunakan kabel maupun nirkabel. Contoh penggunaan sensor network adalah sistem monitor tingkat polusi atau kontaminasi udara, pengendali reaktor nuklir, sistem deteksi kebakaran atau semburan panas bumi, area habitat monitoring, object tracking, trafic monitoring ataupun kondisi lainnya (Ilyas and Mahgoub, 2004).

Pada prinsipnya pembacaan kondisi oleh sensor ini akan diinformasikan secara realtime dan keamanan data yang terjamin hingga diterima oleh pengolah data. Beberapa karakteristik dari sensor network diantaranya ;

a. digunakan pada daya yang terbatas,

b. dapat ditempatkan pada kondisi lingkungan yang keras,

c. dapat digunakan untuk kondisi dan pemrosesan data secara mobile mempunyai topologi jaringan yang dinamis, dengan sistem node yang heterogen,

d. dapat dikembangkan untuk skala besar.

Sensor Network dikembangkan dengan beberapa topologi jaringan yaitu :

a. Topologi jaringan poin to point.

Sistem topologi jaringan dengan point to point memberikan reliability yang lebih baik, karena masing masing sensor secara terpisah tersambung ke host. Sistem dapat dikembangkan dengan menambahkan redundant host. Topologi jaringan ini dapat dilihat seperti Gambar 9 berikut ini.
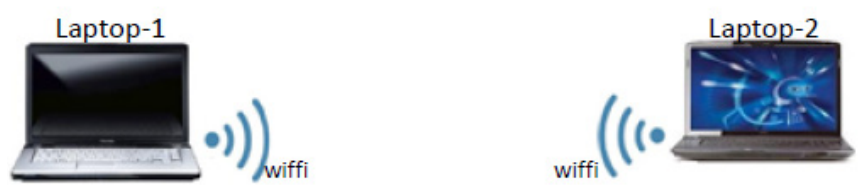

Gambar 9. Topologi Jaringan Point-to-point

(Sumber : Olahan Penulis, 2014) 
Topologi jaringan poin to point, membutuhkan biaya lebih mahal dan management konfigurasi yang agak sulit. Semua data dan informasi hanya diproses oleh host, karena setiap node sensor terhubung langsung ke host.

b. Topologi jaringan multidrop.

Pada topologi jaringan multidrop, setiap sensor memberikan informasi kepada common medium. Hal ini membutuhkan ketelitian dalam protokol hardware dan software. Sistem multidrop ini juga disebut sebagai jaringan dengan sistem bus dan jika dibandingkan dengan topologi point to point terdapat sambungan yang lebih sederhana dalam penyambungan ke host, karena setiap sensor tersambung dalam satu common medium untuk selanjutnya tersambung ke host (Sibarani, 2008). Topologi jaringan ini dapat dilihat pada Gambar 10.

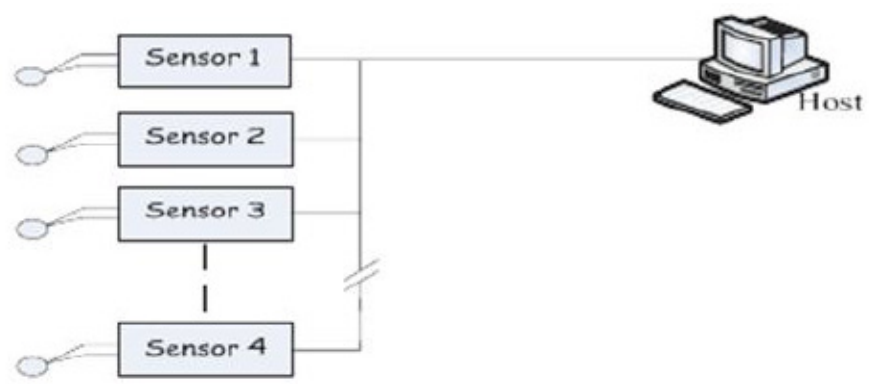

Gambar 10. Topologi Jaringan Multidrop.

(Sumber, Sibarani, 2008)

\section{Protokol Komunikasi}

Protokol komunikasi merupakan tatacara yang mengatur proses komunikasi dan aliran data. Protokol komunikasi dikembangkan untuk membentuk jaringan komputer. Sekitar tahun 70-an Department of Defence (DoD) di Amerika Serikat mempelopori 
pengembangan protokol jaringan komputer yang tidak terikat pada jenis komputer maupun media komunikasi yang digunakan. Protokol yang dikembangkan diberi nama Internet Protocol (IP) dan Transmission Control Protocol (TCP). Jaringan komputer menggunakan TCP/IP kini lebih dikenal sebagai jaringan Internet.

Perkembangan protokol jaringan komputer ini telah dikembangkan dalam beberapa model selain model referensi TCP/IP, seperti model referensi OSI, model bybrid dan model yang lainnya. Sistem protokol komunikasi ini dibuat dalam model lapisan atau layer. Secara umum lapisan protokol dalam jaringan komputer menurut model referensi OSI dibagi atas tujuh lapisan atau layer yang terdiri dari lapisan terbawah hingga tertinggi yaitu :
a. Physical layer
b. Data link layer
c. Network layer
d. Transport layer
e. Session layer
f. Presentation layer
g. Application layer.
Masing-masing lapisan mempunyai fungsi masing-masing dan tidak tergantung antara satu dengan lainnya (Forowzan, 2007). 


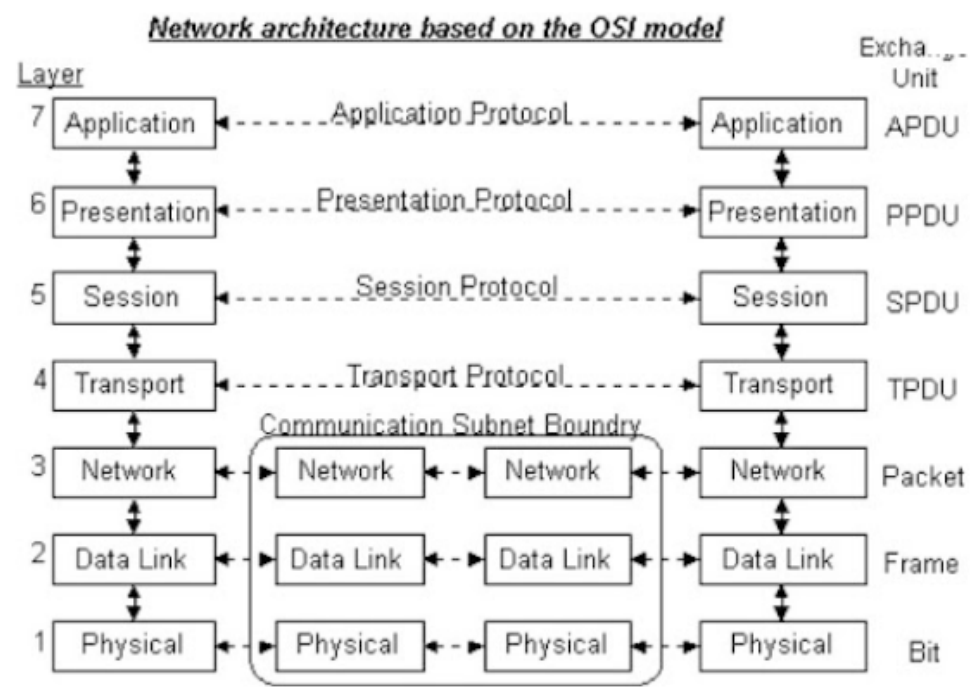

Gambar 11. Protokol komunikasi model referensi OSI.

(Sumber : Forowzan, 2006)

Dari ketujuh lapisan ini hanya physical layer yang merupakan perangkat keras selebihnya merupakan perangkat lunak. Physical layer merupakan media penghubung untuk mengirimkan informasi digital dari satu komputer ke komputer lainnya.

a. Protokol TCP/IP

TCP/IP protokol adalah jaringan dengan teknologi "packet Switching " yang berasal dari proyek Development of Defense Advanced Research Project Agency (DARPA) ditahun 1970-an yang dikenal dengan nama ARPANET. TCP/IP adalah protokol yang tersedia pada NT 4.0 dengan layanan aplikasi berorientasi Internet dan Intranet. TCP/IP sendiri sebenarnya merupakan suite dari gabungan beberapa protokol. Di dalamnya terdapat protokol TCP, IP, SMTP, POP, dan sebagainya. Protokol TCP/IP mempunyai model 
layer yang sedikit berbeda dengan model referensi OSI, seperti terlihat pada Gambar 12.

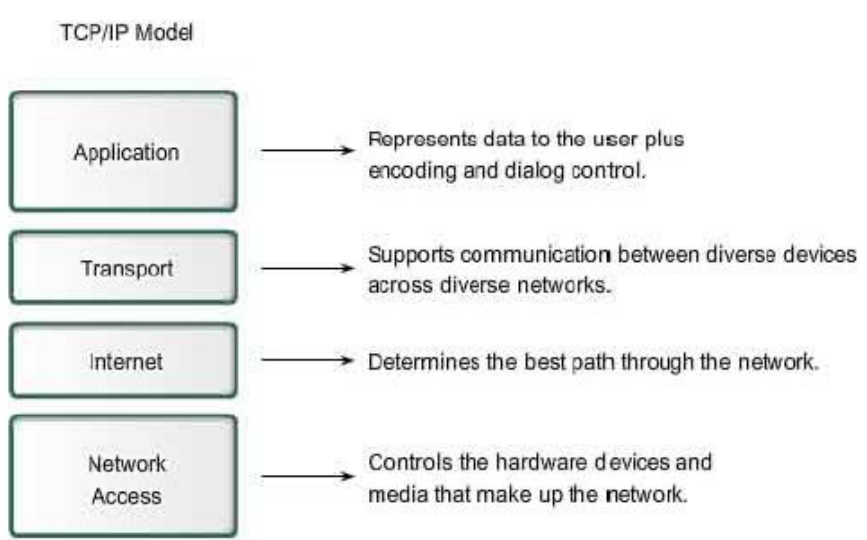

Gambar 12. Protokol komunikasi model TCP/IP

(Sumber : Todd Lammle, 2005)

\section{Transmission Control Protocol (TCP)}

Transmission Control Protocol (TCP) melakukan transmisi data per segmen, artinya paket data dipecah dalam jumlah yang sesuai dengan besaran paket, kemudian dikirim satu persatu hingga selesai. Agar pengiriman data sampai dengan baik, maka pada setiap paket pengiriman, TCP akan menyertakan nomor seri (sequence number). Komputer penerima paket tersebut harus mengirim balik sebuah sinyal ACKnowledge dalam satu periode yang ditentukan. Bila pada waktunya penerima belum juga memberikan ACK, maka terjadi " time out " yang menandakan pegiriman paket gagal dan harus diulang kemabali. Model protokol TCP ini disebut sebagai connection oriented protocol. Pengiriman data dilakukan melalui port yang merupakan pintu masuk datagram dan paket data. Port data dibuat mulai dari 0 sampai dengan 65.536. Port 0 sampai dengan 1024 disediakan untuk layanan standar, seperti FTP, TELNET, 
Mail, Web dan lainnya. Port ini lebih dikenal dengan nama well known port (Sibarani, 2008).

\section{Internet Protocol (IP).}

Internet protocol menggunakan IP-address sebagai identitas. Pengiriman data akan dikemas dalam paket dengan label berupa $\mathrm{IP}$-address pengirim dan IP-address penerima. Apabila IP penerima melihat pengiriman paket tersebut dengan identitas IP-address yang sesuai, maka datagram tersebut akan diambil dan disalurkan ke TCP melalui port, dimana aplikasi menunggunya. IP address terbagi dua ( 2 ) bagian, yaitu :

1. Network ID : identitas Jaringan

2. HOST ID : Identitas Komputer

Penulisan IP address terbagi atas 4 angka, yang masingmasing mempunyai nilai maksimum 255 ( maksimum dari 8 bit) yaitu : IP address : 255.255.255.255 IP Address dirancang dalam beberapa CLASS yang didefinisikan sebagai berikut :

\section{Class A :}

Network id Host Id ( 24 bit ) ; 0 $\mathrm{xxx} \mathrm{xxxx} \mathrm{xxxx} \operatorname{xxxx} \mathrm{xxxx} \operatorname{xxxx} \mathrm{xxxx} \mathrm{x}$ Class B :

Network Id Host Id ( 16 bit ) ; 10xx $\mathrm{xxxx} \mathrm{xxxx} \mathrm{xxxx} \mathrm{xxxx} \mathrm{xxxx} \mathrm{xxxx} \mathrm{x}$ Class C :

Network Id Host Id ( 8 bit ) ; 110 $\mathrm{x} x \mathrm{xxx} \mathrm{xxxx} \mathrm{xxxx} \mathrm{xxxx} \mathrm{xxxx} \mathrm{xxxx} \mathrm{xx}$

\begin{tabular}{|c|c|}
\hline No. Port & Keterangan \\
\hline 21 & FTP \\
110 & POP 3 \\
23 & Telnet \\
25 & SMTP \\
80 & HTTP/Web \\
\hline
\end{tabular}

Tabel 4. Pembagian range IP 
Dengan demikian untuk menentukan class A, B, atau C, cukup dilihat dari angka 8 bit pertama yaitu :

10.123.7.15: Class $A$

190.24.43.20: Class $B$

202.159.23.10: Class $C$

Untuk IP address yang legal akan diberikan oleh Network Information Center (NIC), yang mana setiap orang dapat memintanya melalui Internet Service Provider (ISP).

\section{Embedded Webserver ATmega328 Board}

Embedded Web Server ATmega328 adalah papan mikrokontroler berdasarkan ATmega328. Modul ini memiliki 14 digital input/output pin (dimana 6 dapat digunakan sebagai output PWM), 6 input analog, osilator kristal $16 \mathrm{MHz}$, koneksi USB, jack listrik, header ICSP dan tombol reset. Modul ini berisi semua yang diperlukan untuk mendukung mikrokontroler, cukup menghubungkannya ke komputer dengan kabel USB atau kekuasaan itu dengan adaptor AC-DC atau baterai untuk mengaktifkan modul (Bejo, 2008). Spesifikasi ATmega328 memiliki fitur-fitur berikut.
a. MicrocontrollerATmega328,
b. Operating Voltage5Vinput,
c. Voltage (recommended)7-12Vinput,
d. Voltage (limits) 6-20V,
e. Digital I/O Pins14 (of which 6 provide PWM output),
f. Analog Input Pins6DC Current per I/O Pin40 mADC,
g. Current for 3.3V Pin50 mA,
h. Flash Memory32 KB (ATmega328) of which $0.5 \mathrm{~KB}$ used by bootloader,
i. SRAM2 KB (ATmega328),
j. EEPROM1 KB (ATmega328), 
k. Clock Speed16 MHz.

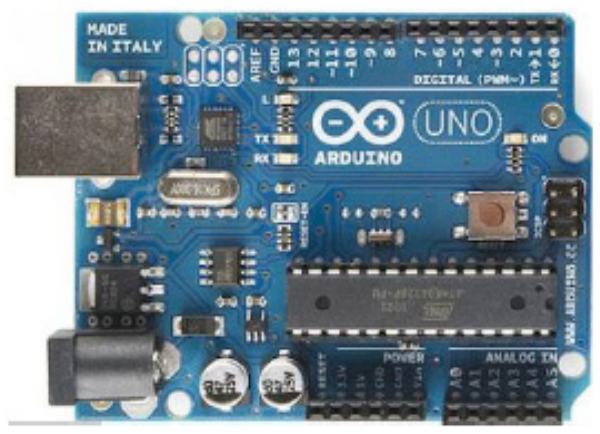

Gambar 13. Embedded Web Server ATmega328

(Sumber : http://www.ermicro.com/blog/?p=1773)

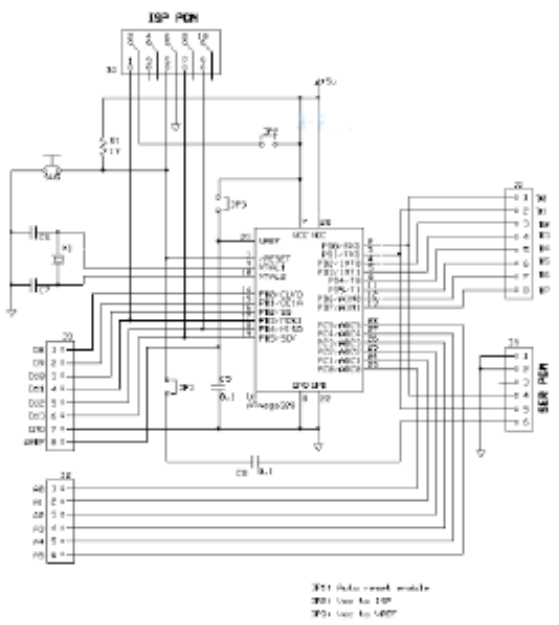

Gambar 14. Skema Rangkaian Embedded Web Server ATmega328

(Sumber : Wardhana, 2006) 


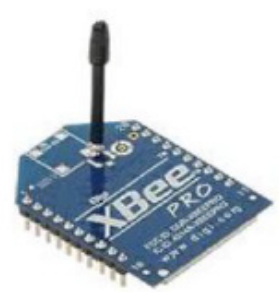

(a)

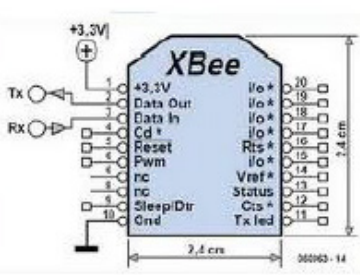

(b)

Gambar 15. (a) XBee 1mW Wire Antenna, (b) Skema Rangkaian Xbee (Sumber : http://www.ermicro.com/blog)

\section{Sensor Getar Accelerometer}

Accelerometer adalah alat yang digunakan untuk mengukur percepatan, mendeteksi dan mengukur getaran (vibrasi), dan mengukur percepatan akibat gravitasi (inklinasi). Sensor accelerometer mengukur percepatan akibat gerakan benda yang melekat padanya (Ekhtiari, 2011).

Accelerometer dapat digunakan untuk mengukur getaran pada mobil, mesin, bangunan, dan instalasi pengamanan. Sensor accelerometer juga dapat diaplikasikan pada pengukuran aktivitas gempa bumi dan peralatan-peralatan elektronik, seperti permainan 3 dimensi, mouse komputer, dan telepon. Untuk aplikasi yang lebih lanjut, sensor ini banyak digunakan untuk keperluan navigasi. Percepatan merupakan suatu keadaan berubahnya kecepatan terhadap waktu. Bertambahnya suatu kecepatan dalam suatu rentang waktu disebut juga percepatan (acceleration). Jika kecepatan semakin berkurang daripada kecepatan sebelumnya, disebut deceleration. Percepatan juga bergantung pada arah/orientasi karena merupakan penurunan kecepatan yang merupakan besaran vektor. Berubahnya arah pergerakan suatu benda akan menimbulkan percepatan pula. Untuk memperoleh data jarak dari sensor accelerometer, diperlukan 
proses integral ganda terhadap keluaran sensor.

Accelerometer MMA7361.

Menurut Seifert (2007), beberapa spesifikasi teknis dari sensor ini adalah :

a. Catu daya 3,3VDC - 8VDC,

b. Berbasis IC MMA7361 dari Freescale,

c. Tersedia switch untuk pemilihan sensitivitas $(+/-1.5 \mathrm{~g}$ atau + /- 6g),

d. Memiliki output data digital untuk masing-masing axis,

e. Memiliki urutan pinout dan konektor kabel yang kompatibel penuh dengan modul IO Expansion Shield For Arduino(V5) dari DFRobot.

Dapat dihubungkan ke berbagai macam mikrokontroler yang memiliki ADC.

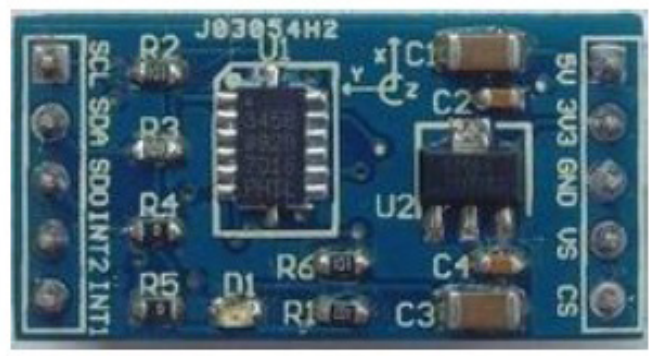

Gambar 16. Accelerometer tipe MMA7361

(Sumber : http://www.ermicro.com/blog, 2012)

5. Mesin Bubut Horizontal

a. Prinsip Kerja Mesin Bubut

Poros spindel akan memutar benda kerja melalui piringan pembawa sehingga memutar roda gigi pada poros spindel. Melalui roda gigi penghubung, putaran akan disampaikan 
ke roda gigi poros ulir. Oleh klem berulir, putaran poros ulir tersebut diubah menjadi gerak translasi pada eretan yang membawa pahat. Akibatnya pada benda kerja akan terjadi sayatan yang berbentuk ulir (digilib.petra.ac.id, 2012).

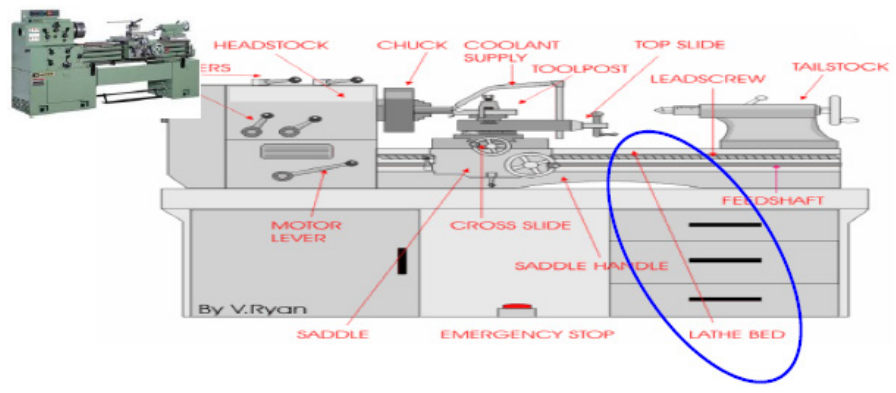

Gambar 17. Mesin Bubut CNC

(Sumber : digilib.petra.ac.id, 2012)

b. Bagian Utama Mesin Bubut

1) Alas / Landasan (Lathe Bed)

Yang dimaksud dengan alas mesin adalah alas mesin bubut yang terbuat dari bahan baja tuang. Penampangnya berbentuk " $V$ " dan berfungsi sebagai tempat kedudukan bagian-bagian utama mesin bubut, seperti: Kepala tetap, Kepala lepas dan Eretan.

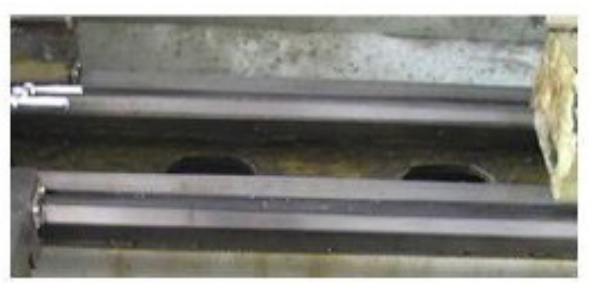

Gambar 18. Bad Mesin bubut (Lathe bed)

(Sumber : digilib.petra.ac.id, 2012)

2) Kepala tetap (head stock) 
Di bagian sebelah kiri dari alas mesin bubut terdapat kepala tetap.Di dalam kepala tetap, spindle utama terpasang pada bantalan, fungsinya untuk memindahkan putaran ke benda kerja, spindelharus terpasang kuat dan terbuat dari baja yang kuat, pada umumnya bagian dalam spindel dibuat berlubang.3.

3) Kepala lepas (tail stock)

Kepala lepas dipakai sebagai penyangga benda kerja yang panjang, mengebor dan meluaskan lubang (reamer). Kepala lepasdilengkapi dengan kerucut morse, gunanya untuk memasang alat-alat yang akan dipasang pada kepala lepas seperti bor, reamer, senter jalan dan lain-lain. Kepala lepas dapat diangkat dari alas mesin (bed) dan dapatdipasng terkunci dengan baut pengikat, roda pada kepala lepasdapat dipakai untuk menggerakan konis, dengan konis itu selubung (sleeve) dapat terkunci, ada kepala lepas yang selubung digerakkan dengan hidrolik atau kompresor udara, untuk ini tekanan pada benda kerja dapat sama rata.

4) Eretan

Eretan mesin bubut digunakan untuk memegang erat perkakas bubut dan memberikan kepadanya gerakan yang diperlukan (gerakkan ke kiri/ke kanan dan gerakan melintang)

5) Mekanik percepatan

Poros pembuat ulir (lead screw) hanya dipakai untuk membuat ulir, dari kepala tetap, lead screw ini digerakkan melalui kotak roda gigi (gear box) apabila mur setengah (halfnut) yang mencekam poros itu dihubungkan oleh tuas penghubung maka poros berulir menggerakkan eretan dengan arah memanjang. 
Mesin Bubut mempunyai prinsip gerakan dasar yaitu gerakan ke arah melintang dan horizontal dengan sistem koordinat sumbu X dan Z. Untuk arah gerakan pada mesin bubut, diberi lambangsebagai berikut :
a) Sumbu $\mathrm{X}$ untuk arah gerakan melintang tegak lurus terhadap sumbu putar.
b) Sumbu $\mathrm{Z}$ untuk arah gerakan memanjang yang sejajar sumbu putar.

c. Spesifikasi dan Karakteristik Mesin Bubut

Spesifikasi mesin ini adalah:

1) Daerah kerja putaran spindel antara 50-3200 rpm,

2) Kecepatan garak pahat arah longitudinal atau melintang;

a) Kecepatan penuh (tak boleh memotong) $700 \mathrm{~mm} /$ menit,

b) Kecepatan secara manual (mode manual) $5-400$ $\mathrm{mm} / \mathrm{menit}$,

c) Kecepatan secara otomatis (mode CNC) $5-499 \mathrm{~mm} /$ menit,

3) Ketelitian gerakan (yang tercantum pada display digital) $0,01 \mathrm{~mm}$,

4) Daerah kerja memanjang $300 \mathrm{~mm}$,

5) Daerah kerja melintang $50 \mathrm{~mm}$,

6) Gaya pemakanan maksimum yang diperbolehkan 1000 $\mathrm{N}$.

Bagian-bagian Mesin Bubut :

1. Tailstock 


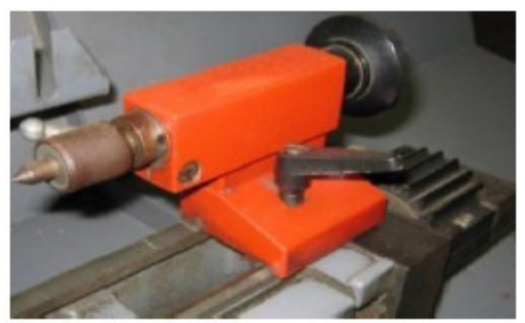

Gambar 19. Tailstock

(Sumber : digilib.petra.ac.id, 2012)

Pada mesin bubut tailstock berfungsi untuk menahan benda kerja yang panjang agar benda kerja tidak oleng dan untuk mencekam pahat drill.

2. Revolver pahat

Pada mesin bubut terdapat revolver pahat yang berguna untuk mencekam pahat dalam jumlah banyak (maksimum 6 buah, 3 buah pahat luar dan 3 buah pahat dalam).

3. Chuck

Pada mesin bubut TU-2A chuck berfungsi untuk mencekam benda kerja.

4. Konfigurasi tombol

Gambar 20. menunjukkan konfigurasi dan tomboltombol atau bagian-bagian untuk mengoperasikan mesin bubut, yang terdiri dari:

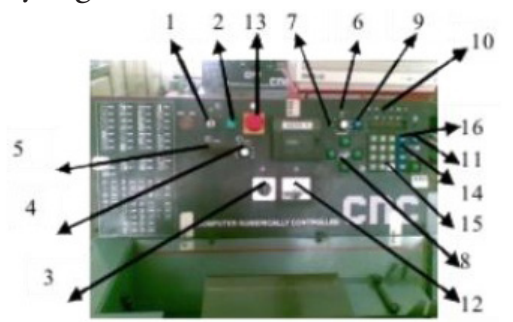

Gambar 20. Konfigurasi tombol operasipada TU-2A

(Sumber : digilib.petra.ac.id, 2012) 
Keterangan Gambar :

1. Saklar utama, digunakan untuk menghidupkan/mematikan mesin

2. Lampu indikator, digunakan sebagai petunjuk bahwa jika lampu hidup maka mesin dalam keadaan hidup.

3. Saklar untuk menghidupkan spindle (untuk saklar menunjuk angka 0 - spindle mati, angka 1 - spindle hidup untuk melayani manual, $\mathrm{CNC}$ - spindle hidup untuk pelayanan $\mathrm{CNC} /$ otomatis).

4. Tombol untuk mengatur besar putaran spindle.

5. Display penunjuk besar putaran spindle.

6. Tombol untuk mengatur kecepatan asutan ( untuk mode manual ).

7. Lampu indikator untuk mode manual.

8. Tombol asutan untuk arah $\mathrm{Z}$ dan $\mathrm{X}$ untuk mode manual.

9. Tombol gerakan cepat jika di tekan bersamaan dengan mode asutan (no 8), maka gerak asutan menjadi cepat. Kecepatan asutan diatur dengan tombol no 6.

10. Display yang meunjukkan harga $X$ dan $Z$ dari gerakan eretan/pahat dalam perseratus $\mathrm{mm}$. data ini juga terlihat di monitor.

11. Switch untuk mengubah mengubah dari pelayanan/ mode manual ke CNC atau sebaliknya pada mesin ini tersedia dua macam pelayanan/mode, yaitu dapat dipakai secara manual (mode manual) atau dipakai secara otomatis yang menggunakan program $\mathrm{CNC}$ (mode CNC).

12. Amperemeter, menunjukkan besar arus yang dipakai 
saat mesin digunakan. Pemakaian arus diharapakan tidak lebih dari $2 \mathrm{~A}$, sebab kalau arus terlalu besar menunjukkan beban pada mesin sangat besar yang dapat menimbulkan kebakaran.

13. Emergency Stop Botton, merupakan saklar darurat.

14. Tombol DEL, untuk menghapus data/sajian.

15. Tombol pengalih untuk mengaktifkan jalannya X ke $\mathrm{Z}$ atau sebaliknya.

16. Tombol INP, untuk memasukkan data yang akan dijelaskan kemudian.

Selain itu juga ada tombol-tombol untuk gerak manual arah $+\mathrm{X},-\mathrm{X},+\mathrm{Y},-\mathrm{Y},+\mathrm{Z}$ dan $-\mathrm{Z}$, yang terletak disebelah tombol angka (digilib.petra.ac.id, 2012).

\section{Implementasi Teknologi Mikrokontroler Pada Mesin Bubut Horizontal}

1. Perancangan Sensor Getar

Sensor getar yang dirancang terdiri atas 3 bagian, yaitu sensor getar (ADXL335), mikrokontroler ATMEGA328 di Arduino dan Komputer Kontrol. ADXL335 bertugas membaca dan menangkap data getaran dari mesin bubut dalam 3-sumbu ( $\mathrm{x}, \mathrm{y}, \mathrm{z}$ ) dan meneruskan ke mikrokontroler melalui pin digital in pada Arduino. Arduino UNO adalah minimum system board dengan mikrokontroler ATMEGA328 sebagai memori utama, include downloader, bersifat open source dan mudah digunakan. Arduino selanjutnya menerima data getaran ADXL, mengkalibrasi dan mengirim hasil kalibrasi getaran ke port serial komputer kontrol melalui kabel serial USB. Komputer kontrol bertugas mengambil data getar dari port, mengirim dan menyimpan ke database, mengolah menjadi grafik dan nilai desimal tertentu serta 
menampilkan ke layar komputer melalui sebuah interface software. Secara keseluruhan sensor getar untuk pelayanan perawatan mesin bubut horisontal dirancang seperti Gambar 21 berikut.

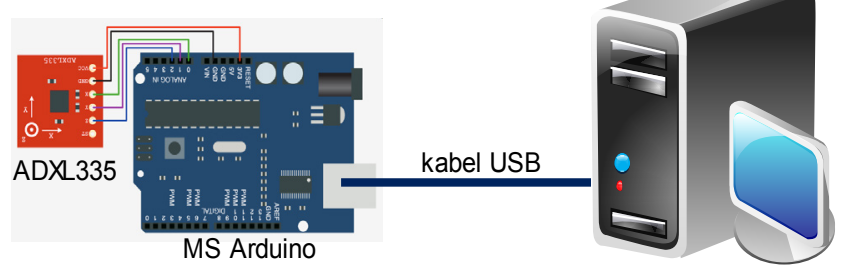

Gambar 21. Rancangan Sensor Getar

ADXL335 adalah modul 3-axis kecil dan tipis berdaya rendah $350 \mu \mathrm{A}$ dalam tegangan operasi 1.8 volt hinggga 3.6 volt. Modul ini dapat mengukur percepatan sebuah benda dengan sensitifitas $\pm 3 \mathrm{~g}$ baik percepatan statis maupun dinamis, tubrukan benda dan getaran. Bandwith accelerometer dapat dipilih menggunakan $\mathrm{C}_{\mathrm{X}}$, $\mathrm{C}_{\mathrm{Y}}$ dan $\mathrm{C}_{\mathrm{Z}}$ pada pin output-nya. Lima pin keluaran dari ADXL335 terdiri atas 3 pin data $(x, y, z)$ yang dikoneksikan ke pin-pin digital dari Arduino (A0, A1, A2), Pin Tegangan yang dihubungkan ke pin 3.3 volt arduino dan pin gnd yang dihubungkan ke pin ground-nya arduino.

Hasil interkoneksi sensor dengan mikrokontroler seperti pada gambar 22 berikut.

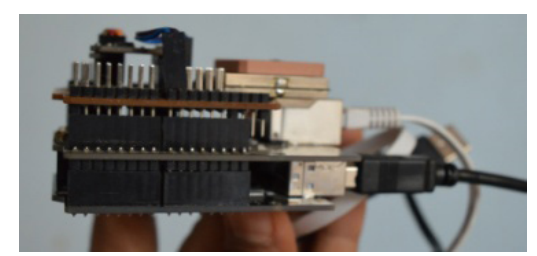

Gambar 22. Sensor Getar dengan ADXL335 
Rancangan pembacaan data getaran dari sensor ADXL335 selanjutnya digambarkan melalui flow chart pada gambar 23 berikut ini :

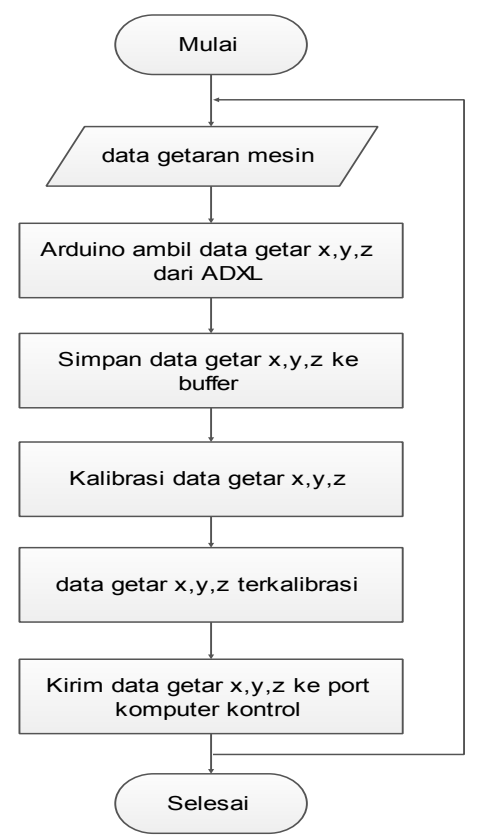

Gambar 23. Rancangan aliran data dari sensor ADXL335

Proses pembacaan getaran dimulai ketika mesin dibunyikan dan ADXL335 menangkap getaran analog mesin. Getaran analog ini akan dikonversi oleh ADXL335 menjadi getaran digital dan mengalir melalui pin $\mathrm{x}, \mathrm{y}, \mathrm{z}$ menuju ke Atmega328 di arduino. Arduino menerima aliran data digital axis sensor melalui pin A0, A1 dan A2 dan menampung ke sebuah buffer yang dibentuk secara software. Pembentukan buffer dimaksudkan agar semua data getaran mesin yang ditangkap tidak terbuang (hilang) tetapi diolah sebagai data getaran. Nilai getaran yang dibuffer kemudian secara 
berurutan dikalibrasi untuk mendapatkan nilai ideal getaran dan dikirim ke port untuk proses selanjutnya.

\section{Proses Kalibrasi Sensor Getar}

Proses klaibrasi sensor dilakukan secara software berdasarkan persamaan matriks. Secara numerik, kalibrasi accelerometer diawali dengan menentukan tegangan pada masing-masing axis accelerometer berikut :

$$
\left[\begin{array}{l}
x \\
y \\
z
\end{array}\right]=\left[\begin{array}{ccc}
\frac{1}{\text { skala faktor } x} & 0 & 0 \\
0 & \frac{1}{\text { skala faktory }} & 0 \\
0 & 0 & \frac{1}{\text { skala faktor } z}
\end{array}\right] x\left[\begin{array}{l}
x_{\text {read }}-\text { sensit_x } \\
y_{\text {read }}-\text { sensit_y } \\
x_{\text {read }}-\text { sensit_z } z
\end{array}\right]
$$

Nilai $x, y, z$ adalah nilai sensor terkalibrasi yang selanjutnya dipakai sebagai data getaran yang diberikan ketika sensor dalam keadaan tidak bergetar (diam). Selanjutnya dicari percepatan (acceleration) getaran masing-masing axis dengan persamaan :

$$
\begin{aligned}
A_{x_{-} \text {axis }} & =\frac{V_{x-\text { axis }}}{\text { sensitivity }-x} \\
A_{y_{-} \text {axis }} & =\frac{V_{y \text {-axis }}}{\text { sensitivity }-y} \\
A_{z_{-} \text {axis }} & =\frac{V_{z-\text { axis }}}{\text { sensitivity }-z}
\end{aligned}
$$

dan Percepatan Referensi $\left(\mathrm{A}_{\text {ref }}\right)$ dengan persamaan pytagoras

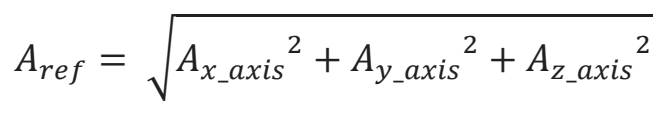


Nilai $x, y$ z dari ADXL335 diproses dalam Arduino, ditentukan nilai zero_G dan scale. Zero_G adalah nilai axis ketika sensor dalam posisi diam tanpa dibalik, sedangkan scale adalah rata-rata perubahan setiap axis. Hasil perhitungan diperoleh nilai zero_G adalah 384, 383 dan 473 untuk x, y, z dan nilai scale adalah 102.3.

Setelah melewati proses kalibrasi, hasil perhitungan menunjukkan bahwa dalam kondisi tidak ada getaran ADXL335 memberikan nilai tegangan pada sumbu $x 0.000$, sumbu y 0.000 dan sumbu z 0.000. Nilai $\mathrm{V}_{\mathrm{x} \_ \text {axis }}, \mathrm{V}_{\text {y_axis }}$ dan $\mathrm{V}_{\text {z_axis }}$ selanjutnya digunakan sebagai acuan untuk tampilan grafik getaran dan nilai A dijadikan referensi untuk menentukan batasan ideal getaran mesin bubut horisontal pada grafik getaran di layar komputer kontrol. Ketika sensor diam, nilai tegangan 3-axis akan stabil pada nilai kalibrasi $(0.000,0.000,0.000)$. Tetapi ketika diberi triger, nilai tegangan akan berubah-ubah. Triger adalah getaran mesin bubut horisontal di laboratorium Teknik Mesin Politeknik Negeri Kupang. Proses kalibrasi software dilakukan dengan tahapan seperti gambar 24 berikut :

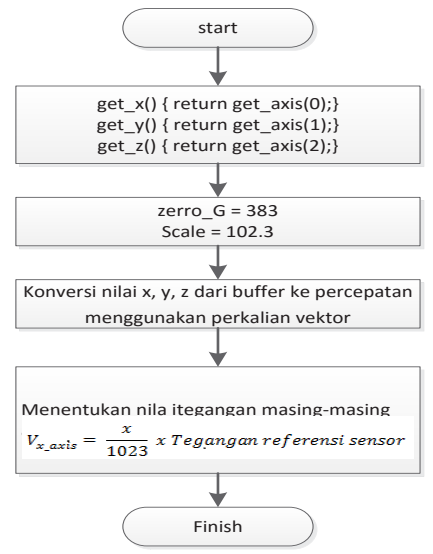

Gambar 24. Proses Kalibrasi Sensor 
Output sensor yang terbaca di komputer sebelum dan sesudah kalibrasi ditampilkan pada gambar 25 (a) dan 25 (b) berikut :

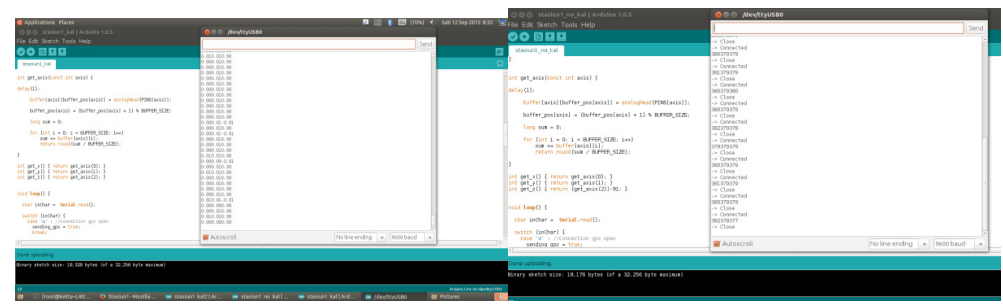

(a)

(b)

Gambar 25. (a), (b) Output getaran sebelum dan sesudah dikalibrasi

Pada gambar 24 terlihat bahwa output getaran yang dihasilkan oleh sensor memiliki 3 nilai berurutan $\mathrm{x}, \mathrm{y}$, z dengan nilai 384, 383 dan 473. Nilai tersebut adalah nilai asli dari sensor ADXL335 yang dikonversi dari getaran analog yang ditangkapnya. Output getaran tersebut belum dapat dijadikan referensi untuk penentuan nilai ideal getaran atau output akhir yang diolah dalam interface, tetapi dikalibrasi dengan persamaan yang sudah ada. Gambar 25 sudah memberikan output getaran terkalibrasi dengan nilai 0.000, 0.000 dan 0.000 untuk masing-masing axis. Nilai inilah yang selanjutnya diolah menjadi nilai ideal dan percepatan (A) untuk pengolahan data di komputer.

\section{Penentuan Nilai Ideal Sensor Getar}

Kondisi ideal adalah sebuah nilai getaran dalam batasan tertentu ketika mesin masih baru atau terkalibrasi. Penentuan kondisi ideal menggunakan output nilai getaran yang telah dikalibrasi dan dilakukan untuk membedakan mana yang termasuk getaran dari mesin dan mana yang bukan, mengingat sensitifitas sensor ADXL335 yang sangat besar membaca triger sekecil apapun. Nilai kalibrasi yang digunakan untuk menentukan kondisi ideal 
adalah nilai acceleration (A).

Konversi nilai acceleration kedalam rentang nilai ideal dilakukan menggunakan mekanisme parsing dari keadaan terkalibrasi 0.000 setiap axis. Simulasi menunjukkan bahwa ketika sensor melekat pada mesin bubut tanpa getaran, output nilai $x, y, z$ dan A menujukkan nilai 0,000, 0,000, 0,001 dan 0,000. Ketika mesin dihidupkan, nilai $\mathrm{x}, \mathrm{y}, \mathrm{z}$ dan $\mathrm{A}$ berubah dengan kisaran Axis_x : -0.992 s/d +0.994 , Axis_y : -0.981 s/d +1.982 , Axis_z : -1.997 s/d +2.000 dan A : -2.397 s/d +3.076 dimana perubahan nilai acceleration mengikuti setiap perubahan $\mathrm{x}, \mathrm{y}, \mathrm{z}$.

Kisaran nilai acceleration inilah yang dikonversi secara software untuk mendapatkan status perawatan mesin sebagai berikut :

Acceleration menunjukkan $-0.001 \mathrm{~s} / \mathrm{d}+0.001$ : dikonversi 0 - 0.9 : Status mesin BAIK, Beep OFF; Acceleration menunjukkan -0.002 s/d +0.002 : dikonversi Nilai 1 - 1.9 : Status mesin KURANG BAIK, Beep 1 KALI; Acceleration menunjukkan -0.003 s/d +0.003 : Nilai 2 - 2.9 : Status mesin BURUK, Beep ON 2 KALI; Acceleration menunjukkan $-0.004 \mathrm{~s} / \mathrm{d}+0.004$ : Nilai $>3$ : Status mesin SANGAT BURUK, Beep ON 3 KALI. 



\section{Bab III \\ Penutup}

\section{Kesimpulan dan Saran}

Berdasarkan pembahasan dan pemaparan dua riset mengenai implementasi teknologi mikrokontroler yakni di bidang pertanian dan bidang industri, dapat ditarik benang merah bahwa Mikrokontroler Atmega328 pada Arduino dapat digunakan sebagai central processing untuk mengolah penjadwalan proses membuka dan menutup pintu air irigasi menggunakan data waktu secara realtime dari sensor RTC. Pada sistem pintu air irigasi yang dibangun, sensor Real Time Clock (RTC) menjadi komponen utama yang mengatur jadwal membuka dan menutup pintu air irigasi. Dari dua buah pintu air yang dikontrol pada sistem ini, pintu air irigasi pertama beroperasi pada input data 1001 dan 1010, sedangkan pintu air irigasi kedua beroperasi pada input data 0110 dan 0101 . Dengan daya 12 volt 10 A DC, mikrokontroler mampu mengangkat dan menggerakkan pintu air irigasi yang terbuat dari 
plat besi berukuran 100 x $60 \mathrm{~cm}$ dengan ketebalan 3". Kemudian besarnya arus listrik yang mengalir pada masing-masing luaran mikrokontroler ketika sistem kontrol bekerja adalah sebesar 2.7 ampere. Untuk penyempurnaan sistem pintu air irigasi ini, riset ini masih perlu kembangkan dengan melibatkan indikator lain seperti debit air yang tersedia pada masing-masing saluran air dan tekanan air ketika saluran sedang penuh. Indikator-indikator tersebut akan lebih menyempurkan kaulitas pintu air irigasi pintar sebagai sebuah inovasi yang perlu dikembangkan di Indonesia khususnya dalam bidang pertanian.

Sedangkan dari pemaparan dan pembahasan riset kedua, secara umum dapat ditarik kesimpulan bahwa sensor getar Accelerometer ADXL335 dapat dikembangkan untuk mengontrol getaran sebuah mesin bubut horizontal dengan melibatkan mikrokontroler ATMEGA328 pada Arduino. Kemudian, proses kalibrasi sensor getaran mesin bubut dapat dilakukan secara software menggunakan persamaan matriks, serta penentuan nilai ideal getaran mesin dilakukan untuk memudahkan penetapan status getaran dan menentukan bilamana mesin bubut harus dilakukan perawatan. Dalam riset ini, periset hanya menggunakan mesin bubut horizontal yang berada dalam kondisi baik (OK) sehingga getaran yang dihasilkan masih menunjukkan batasan output yang BAIK. Kami selaku tim periset menyarankan agar pada riset-riset selanjutnya diberlakukan juga ketika proses praktik masih berlangsung sehingga kemampuan menetapkan status RAWAT pada mesin tersebut dapat dihasilkan. 


\section{Daftar Pustaka}

Abdollah Ekhtiari, Remote Vehicle Status Monitoring using Wireless Sensor Network, Thesis, Lulea University of Technology, 2011.

ATMEGA328 Datasheet, Atmel-8271-8-bit-AVR-MicrocontrollerATmega48A-48PA-88A-88PA-168A-168PA-328-328P.

--_------, ATmega 328 Data Sheet, http://www.atmel.com, April 2012.

Badan Litbang Pertanian. 2004. Petunjuk Teknis PRA Prima Tani. Badan Penelitian dan Pengembangan Pertanian.

Badan Litbang Pertanian. 2014. Petunjuk Teknis PRA Prima Tani. Badan Penelitian dan Pengembangan Pertanian.

Behrouz A. Forouzan, Data Communications and Networking, Highrer Educatioan, Mc. Grow Hill, 2007 
Bejo, A., CङAVR Rahasia Kemudahan Bahasa C dalam Mikrokontroler Atmega 328, Graha Ilmu, Yogyakarta, 2008.

Charles and Phllips, 2011, Dasar-dasar Sistem Kontrol, Edisi Bahasa Indonesia, Prentich Hall.

---------, Circuit Module, http://www.ermicro.com/blog, April 2012

Elert, G., Acceleration, http://www.hypertextbook.com/physics Mechanics/ Acceleration, November 2008.

Ema Utami dan Sukrisno, Tips dan Trik Bahasa C di GNU/LINUX, ANDI Yogyakarta, 2005

Heryanto, Ary. 2008. Pemrograman Bahasa C untuk Mikrokontroler ATMega 8535. CV Andi Offset. Yogyakarta.

Jogianto Hartono, Konsep Dasar Pemograman Bahasa C, ANDI Yogyakarta, 2002

Laumal F, 2015, Hasil survei tim PPT Politeknik Negeri Kupang ke DI Manikin.

M. Ilyas and Imad Mahgoub, Handbook of Sensor Networks : Compact Wireless and Wired Sensing System, CRC Press, 2004

M. Nur Khomaidi, Kecepatan Motor 3 phasa pada Implementasi Wireless Sensor Network sebagai Pendeteksi Polutan, Jurnal, 2008.

Mariban Sibarani, Sistem Wirelss Sensor Network berbasis IP, Skripsi, UI, 2008

---------, Mesin Bubut, digilib.petra.ac.id, April 2012

Miftakhul Huda, Membuat Aplikasi Mini/Supermarket dengan JAVA, Elexmedia Komputindo, 2011 
Milawarni, Optimalisasi Pemantauan Rehabilitasi Lahan Kritis, Jurnal, 2008

--_-----, MMA7260 Data Sheet, http://www.freescale.com, April 2012.

Muzammil Hussain, dkk, Smart Irrigation System using WSN and GPRS module with three level Access Mechanism, International Journal of Advanced Research in Computer Science and Software Engineering, Volume 5, Issue 1, ISSN : 2277 128X January 2015, pp. 766-768.

N.N, 2010, http://thepowerofhalal.blogspot.com/2010/10/ perencanaan-sistem-jaringan-irigasi.html

N.N, 2014, Atmega328, http://ym-try.blogspot.com/2014/02/ atmega328.html

N.N, 2016, Panduan Pelaksanaan Penelitian dan Pengabdian Kepada Masyarakat di Perguruan Tinggi Edisi X, Direktorat Penelitian dan Pengabdian Kepada Masyarakat Direktorat Jenderal Pendidikan Tinggi Kementerian Pendidikan dan Kebudayaan.

Peraturan Menteri Pekerjaan Umum Republik Indonesia Nomor 13/PRT/M/2012 tentang Pedoman Pengelolaan Aset Irigasi.

Rahmadan, 2003, Evaluasi Kinerja, Saluran Irigasi Jeuram Kabupaten Nagan Raya, Jurnal Teknik Sipil Universitas Sumatra Utara.

Raju, K.R., 1986. Aliran Melalui Saluran Terbuka. Erlangga, Jakarta.

Rinaldi Munir, Algoritma dan Pemograman dalam Bahasa Pacal dan C edisi Revisi, INFORMATIKA, 2011 
Todd Lammle, CCNA, Cisco Certified Nework Associate, Elexmedia Computindo, 2007

Wardhana, L., Belajar Sendiri Mikrokontroler AVR Seri ATmega 328, Andi Offset, Yogyakarta, 2006.

Wardhana, Lingga. 2006. Mikrokontroler AVR Seri ATMega 8535. CV Andi Offset. Yogyakarta.

-, XBee Wire Antenna Data Sheet, http://www.fairchildsemi. com, April 2012. 44 


\section{Index}

A

Close Loop 6

$$
\text { ac } 44,47,49,60
$$

Accelerometer ix, 42, 43, 58

ADC 11, 14, 43

AINo 12

AIN 112

anchorage 9

Application layer 36

Arduino X, 17, 18, 25, 27, 43, 49, 50, 51, 52, 57, 58

AVR 10, 12, 14, 59, 60, 62

C

central processing 16, 19, 57

Charles 5, 60 chuck 47

D

DARPA 37

Data link layer 36 DC $5,16,17,18,25,28,40$,

57

debit 2, 5, 7, 58 del 36 di iv, v, ix, $x, 1,2,3,4,8,9$, $10,14,18,20,21,22$, $23,24,25,27,30,31$, $32,35,48,49,51,53$, $54,57,58,60,61,67$, 68,69 
EEPROM 13, 14

Embedded Web Server ix,

40, 41

$\mathrm{F}$

Fishbone 4, 31

FTP 38

G

gate leaf 9 guide frame 9

$\mathrm{H}$

head stock 44

hidraulik 9

Hoist 9

I

ICP1 11

Interrupt 12

K

kalibrasi 31, 49, 51, 52, 53,

54,58

koefisien 8,9

Kupang 1, 2, 3, 30, 53, 60, 67,

68,69

L

Lathe Bed 44

LCD 16, 17, 20, 21, 22, 23,

24,25

LED1 20, 22, 24, 25

LED2 21, 23, 24, 25 limit switch $17,18,19,20$, $21,22,23,24,25,26$

M

Manikin ix, 1, 2, 3, 10, 60 Mesin Bubut CNC ix, 44 $\mathrm{MHz}$ 13, 40, 41 MIPS 13 MMA7361 ix, 43 MOSI 11 multidrop 35

$\mathrm{N}$

Network layer 36

NTT 1, 69

O

Open Loop 6 OSI ix, $36,37,38$

$\mathrm{P}$

parallelism 13 parameter 2, 5, 6 parsing 55 Petak irigasi 7 Physical layer 36, 37 Point-to-point ix, 34 POP 37 port $\mathrm{x}, 27,38,39,49,51$ PPT 2, 60 Presentation layer 36 Protokol ix, 35, 36, 37, 38 PWM 11, 13, 40 
range IP $x, 39$

realtime vi, 16, 34, 57

reamer 45

Relay $x, 17,18,26,28$

$\mathrm{S}$

Seifert 43

Sensor Network 33, 34, 59,

60

Session layer 36

sipon 8

sleeve 45

SMTP 37

spindle $45,47,48$

SRAM 13

$\mathrm{T}$

To 12

T1 12

tail stock 45

Tailstock ix, 46

TCP/IP ix, 36, 37, 38

TELNET 38

Timer Counter 11

topologi 34,35

Transport layer 36
USART 12,14

V

variabel 5

X

XBee ix, 42, 62

XCK 12

XTAL 11 



\section{Tentang Penulis}

Penulis bernama Folkes E. Laumal, ST, MT., merupakan dosen Politeknik Negeri Kupang kelahiran Kalabahi, 6 Februari 1976. Mengenyam pendidikan S1 Teknik Elektro di Universitas Nusa Cendana dan menamatkannya pada tahun 2000. Penulis menempuh Magister Teknik Elektro (S2) di Institut Teknologi Bandung (ITB) tamat tahun 2013. Karya-karya ilmiah yang pernah ditulisnya yaitu : Komunikasi Data antar Komputer menggunakan interface RS232 yang dipublikasikan pada Jurnal MITRA Politeknik Negeri Kupang Tahun VII No. 2, Agustus 2006 dan Pengembangan Rangkaian Logika berbasis JK Flip-flop menggunakan metode Karnaugh Map (Penggerak Motor Stepper) yang dipublikasikan pada Jurnal STUDIA TEKNOLOGIA Politeknik Negeri Kupang Tahun I No. 2, September 2008.

Pengalaman penelitian yang pernah dilakukannya antara lain; Komunikasi Data Antar-komputer Menggunakan RS232 
(2004, menjabat sebagai Ketua), Simulasi Lampu Lalu lintas 3 arah menggunakan JK Flip-flop (2006, menjabat sebagai Ketua), Simulasi Pengisian Bak Air menggunakan JK Flip-flop (2007, sebagai anggota), Pengembangan Rangkaian Logika berbasis JK Flip-flop menggunakan metode Karnaugh Map (2008, menjabat sebagai Ketua) dan Pembuatan Simulator Krakteristik Dioda untuk Kebutuhan Praktek Mahasiswa Teknik Elektro (2010, sebagai anggota). Penelitian-penelitian tersebut seluruhnya mendapat sumber dana dari DIPA Politeknik Negeri Kupang.

Di samping menyusun karya tulis ilmiah dan aktif melakukan riset, penulis juga aktif dalam kegiatan pengabdian masyarakat, yakni : Pengabdian Kepada Masyarakat/Penyuluhan tentang penggunaan lampu hemat energi dan pemasangan lampu jalan di Kelurahan Lasiana, Kec. Kelapa Lima, Kota Kupang (2004), Pengabdian Kepada Masyarakat/Pemasangan Lampu jalan dan sosialisasi program konservasi dan hemat energi di Kelurahan Lasiana, Kec. Kelapa Lima, Kota Kupang (2005), Kegiatan Profesional/Pelatihan Keterampilan Elektronika (Perbaikan Penerima TV warna) bagi Pemuda Karang Taruna di Kelurahan Oesapa, Kota Kupang (2006), Pengabdian Kepada Masyarakat/Sosialisasi Program Hemat Energi dan Pemasangan Lampu Jalan di Kompleks RSS Oesapa RT/RW 045/014 Kel. Oesapa, Kec. Kelapa Lima, Kota Kupang (2007), pada 2008 penulis melaksanakan tiga program pengabdian masyarakat yakni Pengabdian Kepada Masyarakat/ Sosialisasi Program Hemat Energi dan Pemasangan Lampu Jalan di Kelurahan Oesapa, Kota Kupang, dan dua program lainnya yang bertempat di Politeknik Negeri Kupang yaitu Kegiatan Profesional/ Pelatihan Pengembangan ICT bagi guru-guru SMP yang tergabung dalam Musyawarah Guru Mata Pelajaran (MGMP) dan Kegiatan Profesional/Kursus komputer bagi calon tenaga kerja, kerjasama 
Badan Keswadayaan Masyarakat (BKM) SEROJA Penfui dengan Politeknik Negeri Kupang.

Pada tahun 2009, penulis melaksanakan empat program pengabdian sekaligus yakni Pengabdian Kepada Masyarakat/ Pemasangan Lampu Penerangan Jalan Pekarangan Rumah Tinggal di RT 24 RW 06 Kel. Liliba Kec. Oebobo Kota Kupang, Kegiatan Profesional/Pelatihan Peningkatan Mutu Pendidikan berbasis ICT bagi KKG/MGMP di SMA Kristen 1 Kalabahi, Alor, Kegiatan Profesional/Pelatihan Peningkatan Mutu Pendidikan berbasis ICT bagi KKG/MGMP di Laboratorium SMAN2 Waingapu, Sumba Timur dan Kegiatan Profesional/Pelatihan Peningkatan Mutu Pendidikan berbasis ICT bagi KKG/MGMP di Laboratorium SMAN1 Waikabubak, Sumba Barat. Di samping itu, masih terdapat program pengabdian lainnya yakni Pengabdian Kepada Masyarakat/ Pemasangan Lampu Penerangan Jalan Pekarangan Rumah Tinggal di RT 27 RW 06 Kel. Liliba Kec. Oebobo Kota Kupang (2010), Pengabdian Kepada Masyarakat/Survey kemampuan dan kemauan bayar pelanggan listrik PLN, kerjasama PT. PLN (Persero) dengan Konsorsium Kerjasama Jurusan/Program Studi/Departemen Teknik Elektro UI, ITB, UGM, UNDIP, ITS dan UNUD di Kecamatan Oesao, Kabupaten Kupang (2010), dan Pengabdian Kepada Masyarakat/Penerapan Teknologi Tapat Guna bidang Kelistrikan di Desa Seki Kec. Amabi Oefeto Timur Kab. Kupang (2011).

Penulis dapat dihubungi melalui surel folkeslaumal76@ gmail.com, melalui Telp/Fax: 085239039962 atau dengan mengirim surat ke alamat Jl. Taebenu RT 50 Kel. Liliba Kec. Oebobo ,Kota Kupang, NTT. 
